\title{
Произведения Искусства и Игры Природы в Каталогах Минерального Кабинета Кунсткамеры XVIII в.
}

\section{Works of Art and the Sports of Nature in the Catalogs of the Mineral Cabinet of the Kunstkamera in the Eighteenth Century}

\author{
Дарья Новгородова \\ Минералогический музей имени А. Е. Ферсмана (Москва) \\ Daria Novgorodova \\ Fersman Mineralogical Museum (Moscow) \\ dnovgorodova@gmail.com
}

\begin{abstract}
:
По описаниям в каталогах Минерального кабинета Кунсткамеры прослежено какими значениями в собрании минералов XVIII в. наделялись несколько плакеток флорентийской мозаики и как эти значения менялись. Рассматриваемые флорентийские мозаики в современном Минералогическом музее им. А. Е. Ферсмана РАН входят в Коллекцию поделочных и драгоценных камней, иллюстрирующую применение природного камня в искусстве, а в XVIII в. они обладали научными “минералогическими” значениями и отсылали к важному сюжету играющей Природы. Это их значение исчезает из описаний коллекции Минерального кабинета в 1788 г., однако нарратив lusus Naturae до настоящего времени сохраняется в устной музейной практике.

In this article we trace how several plaquettes of Florentine mosaics have been interpreted in the catalog descriptions of the Mineral Cabinet of the Kunstkamera in the eighteenth century and how these interpretations changed. The Florentine mosaics considered here are currently housed in the modern A. E. Fersman Mineralogical Museum of the Russian Academy of Sciences in the special Collection of Gems and Decorative Stones that serves to illustrate the use of natural stone in art. However, in the eighteenth century the mosaics carried scientific "mineralogical" meanings and illustrated the important theme of "playful nature." This meaning disappears from the descriptions of the collections of the Mineral Cabinet in 1788, but the narrative lusus naturae is preserved in the oral tradition of the museum.
\end{abstract}

Keywords:

Mineral cabinet, Kunstkamera, mosaic, Fersman Mineralogical Museum, catalogues, collection, figured stones, lusus Naturae, peitra dura, marmor.

\section{Введение}

О коллекции Минерального кабинета Кунсткамеры XVIII в., ${ }^{1}$ первого научного минералогического собрания России, мало что известно. Мы знаем историю имен или историю событий, ${ }^{2}$ связанных с этой коллекций, но не представляем ее ни

\footnotetext{
${ }^{1}$ Принятые хронологические рамки Минерального кабинета Кунсткамеры 1716-1836 гг., позже он был преобразован в самостоятельный академический музей, ныне Минералогический музей им. А. Е. Ферсмана РАН (Российской академии наук).

2 И. Бакмейстер, Опыт о библиотеке и кабинете редкостей и Истории Натуральной Санктпетербургской Императорской Академии Наук (Санкт-Петербург: Типография морского шляхетского кадетского Корпуса, 1779) (I. Bakmeister, Opyt o biblioteke i kabinete redkostei i Istorii
} 
предметно в ее материальности и целостности, потому что, как и во многих старых музеях, за зоо лет она оказалась рассеяна, ни, что еще важнее, концептуально.

Преемник Минерального кабинета Кунсткамеры, Минералогический музей им. A. Е. Ферсмана Российской академии наук, сохраняет в своем собрании не только первые российские коллекции минералов, сформированные в XVIII в., “старые камни," но и связанные с ними “старые значения": сохранившиеся на старинных этикетках устаревшие названия минералов, иногда даже не вошедшие в минералогические справочники, старые каталоги, описывающие состав музейной коллекции на латинском языке и сообразно минералогическим систематикам, развитым в XVIII в. и забытым уже к XIX в. И эта часть музейного собрания, которую можно назвать "коллекцией значений," не менее важна, чем вещественная. Ведь отличие собраний XVIII в. от современных состоит не столько в разнице их предметного состава, сколько в самом способе формировать из разрозненных вещей единое целое - коллекцию, присваивая предметам новые значения и смыслы. Эти уникальные способы работы с предметами, особую манеру конструирования из них коллекции, сохранили каталоги Минерального кабинета, источники, в наиболее полной мере представляющие коллекцию как единое целое, подчиненное одной логике. И, хотя с точки зрения современной минералогии эта логика может показаться неясной, и даже "ошибочной" (каталоги Минерального кабинета Кунсткамеры уже начиная с XIX в. характеризовались как ненаучные ${ }^{3}$ ), однако рассматриваемая в контексте культурной истории коллекции, она способна

Natural'noi Sanktpeterburgskoi Imperatorskoi Akademii Nauk (St. Petersburg: Tipografiia morskogo shliakhetskogo kadetskogo Korpusa, 1779); О. П. Беляев, Кабинет Петра Великого. Отделение третье, (Санкт-Петербург: Имп. Типография, 18оo) (О. P. Beliaev, Kabinet Petra Velikogo, Otdelenie tret'e (St. Petersburg: Imp. Tipografiia, 1800)); И. Шумахер, Палаты Санктпетербургской императорской Академии наук Библиотеки и Кунсткамеры (Санкт-Петербург: Печ. при Имп. Акад. Наук, 1744 ) (I. Shumakher, Palaty Sanktpeterburgskoi imperatorskoi Akademii nauk Biblioteki i Kunstkamery (St. Petersburg: Pech. pri Imp. Akad. Nauk, 1744)). См. также работы сотрудников Минералогического музея им. А. Е. Ферсмана РАН: Д. И. Сольский “Очерк истории Минералогического музея Академии наук СССР (дореволюционный период),” Труды Минералогического музея, вып. 11 (1961): 220-230 (D. I. Sol'skii, “Ocherk istorii Mineralogicheskogo muzeia Akademii nauk SSSR (dorevoliutsionnyi period)," Trudy Mineralogicheskogo muzeia, vyp. 11 (1961): 220-230); Г. П. Барсанов, В. А. Корнетова, “История развития Минералогического музея им. А. Е. Ферсмана АН СССР за 270 лет (1716-1986)," Cтарейшие минералогические музеи СССР. Очерки по истории геологических знаний, вып. 25 (Москва: Наука, 1989): 9-52 (G. P. Barsanov, V. A. Kornetova, "Istoriia razvitiia Mineralogicheskogo muzeia im. A. E. Fersmana AN SSSR za 270 let (1716-1986)," Stareishie mineralogicheskie muzei SSSR. Ocherki po istorii geologicheskikh znanii, vyp. 25 (Moscow: Nauka, 1989): 9-52); А. А. Годовиков, "Основные хронологические даты в истории Минералогического музея им. А. Е. Ферсмана АН СССР,” Старейшие минералогические музеи СССР, вып. 25, 53-71 (А. А. Godovikov, "Osnovnye khronologicheskie daty v istorii Mineralogicheskogo muzeia im. A. E. Fersmana AN SSSR,” Stareishie mineralogicheskie muzei SSSR, vyp. 25, 53-71).

3 “Не известно [...] какой тогда последуемо было Системе [Системе минералогии, то есть минералогической систематике - Д. Н.], ибо в помянутой росписи [Минеральном каталоге 1745 г. Д. Н.] правильного Систематического порядка не примечается.” См.: В. М. Севергин, “Обозрение Минерального кабинета Императорской Академии наук,” Технологический журнал, т. 11, ч. 1 (СанктПетербург: при Имп. акад. наук, 1814), 11 (V. M. Severgin, “Obozrenie Mineral'nogo kabineta Imperatorskoi Akademii nauk,” Tekhnologicheskii zhurnal, t. 11, ch. 1 (St. Petersburg: pri Imp. Akad. Nauk, $1814), 11)$. Из современных нам источников приведем подобное мнение: “В шкафах [Минерального кабинета Кунсткамеры в 1745 г. - Д. Н.] минералы были расположены довольно беспорядочно; они делились на две большие группы - по внешнему виду. К первой группе относились образцы, не имеющие определенной формы, - “бесформенные ископаемые,” ко второй - кристаллы минералов и окаменелости.” См.: Сольский, “Очерк истории Минералогического музея,” 222 (Sol'skii, “Ocherk istorii Mineralogicheskogo muzeia," 222). 
прояснить как в XVIII в. отдельные предметы наделялись определенными значениями в каталогах, что это были за значения, и почему они были именно такими.

В данной статье представлен один из эпизодов исследования культурной истории коллекции Минерального кабинета Кунсткамеры по ее каталогам ${ }^{4}$ В 2010 году по описаниям самого первого каталога Кунсткамеры 1745 г. удалось идентифицировать несколько плакеток флорентийских мозаик, сохранившихся в фондах Минералогического музея им. А. Е. Ферсмана РАН, ${ }^{5}$ (фигура 1). В статье показано как анализ описаний этих мозаик в последовательном ряду сводных каталогов Минерального кабинета позволяет проявить особые значения, которыми они наделялись в коллекции минералов XVIII в., и как эти значения менялись.
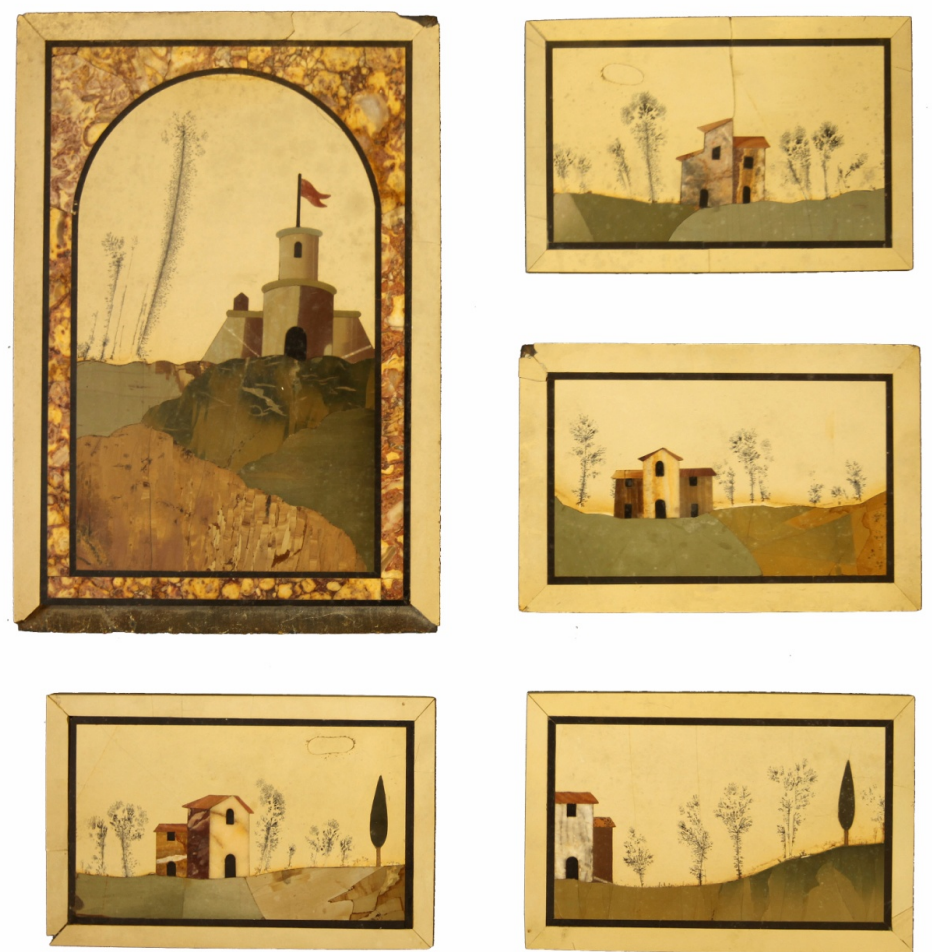

\footnotetext{
${ }^{4}$ Д. Д. Новгородова, “Каталоги Минерального кабинета Кунсткамеры XVIII в.: культурная история коллекции” (кандидатская диссертация, Российский государственный гуманитарный университет, 2017) (D. D. Novgorodova, "Katalogi Mineral'nogo kabineta Kunstkamery XVIIIv.: kulturnaia istoriia kollektsii" (kandidatskaia dissertatsiia, Rossiiskii gosudarstvennyi gumanitarnyi universitet, 2017)). B диссертационное исследование вошли и некоторые материалы настоящей статьи, к тому времени еще не опубликованной и потому не включенной в диссертационную библиографию.

5 Д. Д. Новгородова, “Флорентийская мозаика 'Минерального каталога' в собрании Минералогического музея им. А. Е. Ферсмана РАН," Словарь языка М. В. Л о м о н о с о в а, Н. Н. Казанский (ред.), вып. 5, Минералогия М. В. Ломоносова (Санкт-Петербург: Нестор-История, 2010), 131 - 164 (D. D. Novgorodova, "Florentiiskaia mozaika 'Mineral'nogo kataloga' v sobranii Mineralogicheskogo muzeia im. A. E. Fersmana RAN,” N. N. Kazanskii (red.), Slovar' iazyka M. V. Lomonosov, vyp. 5, Mineralogiia M. V. Lomonosova (St. Petersburg: Nestor-Istoriia, 2010), 131-164).
} 

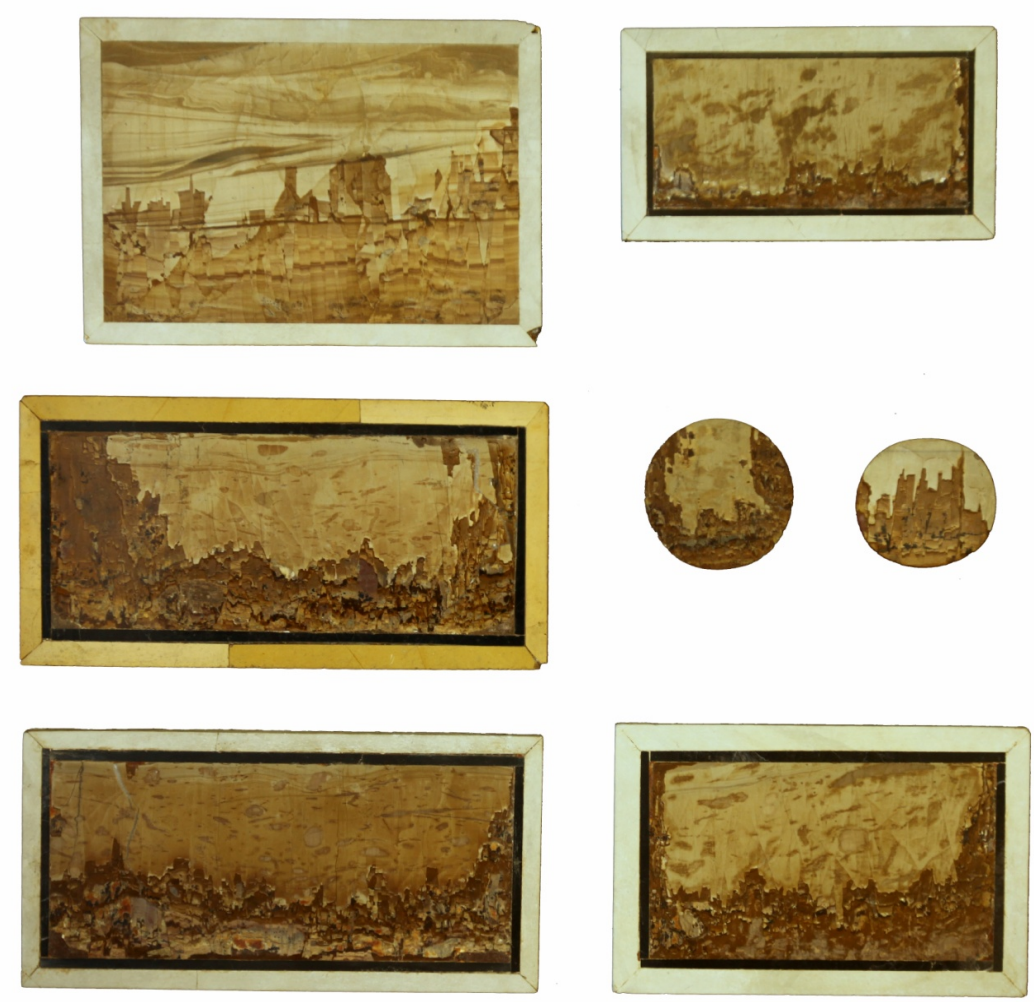

Фигура 1. Флорентийская мозаика из коллекции Минералогического музея им. А. Е. Ферсмана РАН. Инв. номера сверху вниз и слева направо: Флорентийские мозаики с изображением тосканских пейзажей: ПДК-657, ПДК-658, ПДК-659, ПДК-661, ПДК-663; флорентийские мозаики из руинного мрамора: ПДК-2095, ПДК-662, ПДК-2096, ПДК-4202, ПДК-672, ПДК-7835, ПДК-8099.но Фото Д. Новгородовой.

\section{Каталоги Минерального кабинета XVIII в.}

Сводные Каталоги Минерального кабинета составлялись в XVIII в. трижды, в хронологическом порядке они располагаются следующим образом:

1745 г. - Минеральный каталог Гмелина-Аммана-Ломоносова. ${ }^{6}$

1760 г. - Каталог Лемана. ${ }^{7}$

6 "Catalogus minerarum," Musei Imperialis Petropolitani. vol. 1:3, (St. Petersburg: Typis Academiae scientiarum Petropolitanae, 1745). В современных изданиях: "Musei Imperialis Petropolitani," vol. 1, Н. Н. Казанский (ред.), Словарь языка М. В. Ломоносова, вып. 5, 359-467. ("Musei Imperialis Petropolitani," vol. 1, N. N. Kazanskii (red.), Slovar' iazyka M. V. Lomonosova, vyp. 5, 359-467). В русском переводе: В ПСС М. В. Ломоносова приведены латинская часть каталога (содержащая те минералы, которые описал М. В. Ломоносов) и полностью Минеральный каталог в переводе на русский язык. См.: М. В. Ломоносов, “Минеральный каталог," Полное собрание сочинений, т. 5, “Труды по минералогии, металлургии и горному делу 1741-1763 гг." (Москва-Ленинград: Изд. АН СССР, 1954): 7-70 (лат. яз.), 71241 (на рус.) (M. V. Lomonosov, "Mineral'nyi katalog," Polnoe sobranie sochinenii, t. 5, "Trudy po mineralogii, metallurgii i gornomu delu 1741-1763 gg." (Moscow-Leningrad: Izd. AN SSSR, 1954): 7-70 (lat. Iaz), 71-241 (na rus.).

7 Датировка 176о г. дается здесь по записи Иоганна Георги о том, что Иоганн Леман составил этот каталог “около 1760 г." ("circa annum MDCCLX"), по Index Lithophylacei exotici Musei Academiae Scientiarum Imperialis Petropolitanae, MDCCLXXXIX, Архив Минералогического музея им. А. Е. Ферсмана РАН, дело №6o, л. 3. (Arkhiv Mineralogicheskogo muzeia im. A. E. Fersmana RAN, delo no. 6o, l. 3). Мы рассматриваем здесь Lehmann's Catalog, neueres exemplar, bd. I. II, Архив Минералогического музея им. А. Е. Ферсмана РАН, д. №17, 166 л. (Arkhiv Mineralogicheskogo muzeia im. A. E. Fersmana RAN, 
1786-89 гг. - Каталог Георги-Ренованца-Зуева. ${ }^{8}$

Содержательно эти каталоги представляют собой перечни предметов коллекции Минерального кабинета, главным образом минералов, организованных определенным образом, согласно выбранной минералогической систематике (Системе минералогии), ${ }^{9}$ причем в каждом следующем каталоге минералы описаны

d. no. 17, 166 1.). В Архиве Минералогического музея им. Ферсмана хранятся два рукописных экземпляра Каталога Лемана, в которых количество образцов немного различаются. Сотрудник музея Д. И. Сольский датировал их соответственно 1750 г. (Lehmann's Catalog), и 1774 (Lehmann's Catalog, älteres exemplar, bd. I (д. №15), bd. II (д. №16), Архив Минералогического музея им. А. Е. Ферсмана РАН, 82 л.), (Arkhiv Mineralogicheskogo muzeia im. A. E. Fersmana RAN, 82 1.). См.: Сольский, “Очерк истории Минералогического музея,” 223. (Sol'skii, “Ocherk istorii Mineralogicheskogo muzeia,” 223). Однако Сольский не приводит подтверждающих ссылок, и мы не находим подтверждения этих датировок в источниках, поэтому здесь и далее приводится 1760 г. по записи И. Георги.

8 Этот “каталог” состоял уже из четырех частей, каждая описывала специальный раздел коллекции Минерального кабинета. Под одним названием Каталог Георги-Ренованца-Зуева мы объединяем две части минералогического описания коллекции и две - описания окаменелостей. Каталог иностранного минерального кабинета: Index Lithophylacei exotici Musei Academiae Scientiarum Imperialis Petropolitanae. MDCCLXXXIX. Архив Минералогического музея им. А. Е. Ферсмана РАН, Дело №6o, 98 л. (Arkhiv Mineralogicheskogo muzeia im. A. E. Fersmana RAN, delo no. 6o, 98 1.). Списки этого каталога хранятся также в ПФА РАН, например вариант этого каталога в двух частях: I. G. Georgi, Catalogus Mineralium Musaei Academiae Scientarum Imperialis, methodo Wallerii digestus. Anno MDCCLXXXVIII, ПФА РАН, р-д I, оп. 122, №8, 96 л. (PFA RAN, r-d I, op. 122, nо. 8, 96 1.); I. G. Georgi, Index Lithophylacei exotici Musei Academiae Scientiarum Petropolitanae. Anno MDCCLXXXIX, ПФА РАН. p-д I, оп. 122, №8'. 2 л. (PFA RAN, r-d I, op. 122, no. 8, 2 1.) и Каталог российского Минерального кабинета: Index Lithophylacei Rossici Musei Academiae scientarum Petropolitanae. Georgi's Katalog der russichen Mineralien und Gesteine (1786-1789), Copie des Georgischen Originale), Архив Минералогического музея им. А. Е. Ферсмана РАН, д. б/н. 50 л. (Arkhiv Mineralogicheskogo muzeia im. A. E. Fersmana RAN, d. b/n. 50 1.). Каталог окаменелостей отдельно был составлен "адъюнктом Зуевым” (В. Ф. Зуевым). См.: Севергин, “Обозрение Минерального кабинета,” 16. (Severgin, “Obozrenie Mineral'nogo kabineta,” 16.) И также был в двух частях, отдельно описывал российскую и иностранную части коллекции окаменелостей. Здесь мы рассматриваем Каталог российских окаменелостей. См.: Enumeratio fossilium Rossiae indigenorum, classem quartam Systematij mineralogici Walleriani constituentium. Presenté à la Conference le 27 Nov: 1788, Архив Минералогического музея им. A. Е. Ферсмана РАН, дело №1, л. 82-94 (Arkhiv Mineralogicheskogo muzeia im. А. E. Fersmana RAN, delo no. 1, 1. 82-94). Идентификация данного рукописного каталога из Архива Минералогического музея им. Ферсмана РАН проведена в 2014 г. См.: Д. Д. Новгородова, “Списки, описи, каталоги: от перечня вещей к формированию коллекции и становлению науки,” В. А. Ламин, О. Н. Шелегина (ред.), Современные тенденции в развитии музеев и музееведения: Материалы II Всероссийской научнопрактической конференции. Новосибирск, 29 сентября - 3 октября 2014 Г. (Новосибирск: Автограф, 2014), 157. (D. D. Novgorodova, "Spiski, opisi, katalogi: ot perechnia veshchei k formirovaniiu kollektsii i stanovleniu nauki," V. A. Lamin, O. N. Shelegina (red.), Sovremennye tendentsii $v$ razvitii muzeev $i$ muzeevedeniia: Materialy II Vserossiiskoi naucho-prakticheskoi konferentsii. Novosibirsk, 29 sentiabria - 3 oktiabria 2014 g. (Novosibirsk: Avtograf, 2014), 157). Пока неизвестно местонахождение зуевского Каталога “иностранной коллекции” окаменелостей. Приведенный порядок частей каталога (сначала иностранные минералы, потом российские) следует из помещения И. Георги общего предисловия с историей коллекции Минерального кабинета в начале Каталога иностранного минерального кабинета. См.: Index Lithophylacei exotici Musei Academiae Scientiarum Imperialis Petropolitanae. MDCCLXXXIX, Архив Минералогического музея им. А. Е. Ферсмана РАН, Дело №6о. лл. 3,3 об. (Arkhiv Mineralogicheskogo muzeia im. A. E. Fersmana RAN, delo no. 6o, 1l. 3, 3 ob.). В описании окаменелостей, каталог “иностранной части” коллекции также полагался В. Ф. Зуевым первым, это видно из росписи количества образцов по разделам коллекции, приведенной в конце Каталога российских окаменелостей. См.: Enumeratio fossilium, л. 94. Musei Imperialis Petropolitani, vol. 1, 367.

9 Д. Д. Новгородова, “Три каталога из Архива Минералогического музея им. А. Е. Ферсмана РАН,” Новые данные о минералах. Издание Минералогического Музея им. А. Е. Ферсмана РАН, вып. 46 (2011): 114-123 (D. D. Novgorodova “Tri kataloga iz Arkhiva Mineralogicheskogo muzeiia im. A. E. Fersmana RAN,” 
и организованы по-новому: в минеральном каталоге Гмелина-Аммана-Ломоносова по системе И. Гмелина, Каталоге Лемана - по системе И. Лемана, каталоге ГеоргиРенованца-Зуева по системе минералогии шведского минералога Г. Валлериуса.

Составление каждого нового каталога Минерального кабинета в XVIII в. было вызвано формальными причинами: Минеральный каталог 1745 г. был первой описью коллекции и вышел в составе двухтомного сводного “камерального” каталога Кунсткамеры, состоящего из отдельных частей, каталогов всех коллекций Кунсткамеры, Каталог Лемана (176о г.) был составлен для коллекции Минерального кабинета, уцелевшей в пожаре 1747 г., погубившем значительную часть собрания Кунсткамеры; последний в этом ряду Каталог Георги-Реноваца-Зуева был составлен, когда президентом Академии наук стала княгиня Екатерина Романовна Дашкова, в это время Минеральный кабинет был перемещен на новое место и значительно перестроен. Сам факт появления за полвека с 1745 по 1789 гг. трех каталогов коллекции Минерального кабинета, в которых каждый раз одна и та же, постепенно растущая коллекция, описывалась заново, позволяет утверждать, что Минеральный кабинет в XVIII веке существовал в режиме постоянных преобразований, в том числе смысловых. В этой разнице описаний заключена самая яркая черта этих каталогов коллекции XVIII в.: каждый из последующих каталогов полностью отрицал предыдущий; и в этом их отличие от современной инвентарной книги музея, из которой вычеркиваются списанные образцы и заносятся новые.

Культурная история коллекции Минерального кабинета Кунсткамеры, отраженная в последовательном ряду ее каталогов XVIII в., никогда не становилась предметом специального изучения. Наиболее близки теме такого исследования специальные работы, собранные в тематическом выпуске оксфордского Журнала истории коллекций, ${ }^{10}$ посвященном изучению различных коллекций раннего Нового времени по их каталогам. Однако эти исключительно важные работы, как правило, каждая сосредоточена на анализе одного определенного каталога, и никогда - их последовательности. В отличие от упомянутых исследований, благодаря выявленному корпусу источников, мы имеем возможность рассмотреть культурные коннотации коллекции Минерального кабинета и ее отдельных предметов уже не в одном конкретном каталоге, а в исторической последовательности ее сводных каталогов XVIII в.

Мозаики как объект исследования выбраны здесь по двум причинам: во-первых, это пока единственные образцы в коллекции Минералогического музея им. Ф. Е. Ферсмана РАН, идентифицированные по описаниям Минерального каталога 1745 г.; во-вторых, их описания в каталогах минералов и само присутствие в собрании Минерального кабинета достойно специального внимания. Как правило, произведения камнерезного искусства и история минералогических коллекций изучаются отдельно и редко связаны друг с другом. Присутствие произведений искусства в минералогической коллекции, Царстве минералов, не рассматривается как нечто экстраординарное. Естественнонаучные коллекции XVIII в. наследовали кабинетам редкостей, содержащим равным образом как произведения Природы (натуралии), так и вещи, сделанные руками человека (артифициалии). “Институциональное” рождение специальной музейной коллекции, посвященной

Novye dannye o mineralakh. Izdanie Mineralogicheskogo Muzeia im. A. E. Fersmana RAN, vyp. 46 (2011): 114123).

${ }^{10}$ The Journal of the History of Collections, основан в 1989 г. 
применению природного камня в искусстве (коллекция ПДК), ${ }^{11}$ в Минералогическом музее им. Ферсмана РАН произошло сравнительно недавно, в 1925 году, ${ }^{12}$ однако записи первого каталога коллекции Минерального кабинета 1745 г. демонстрируют, что изделия из камня входили в состав коллекции Минерального кабинета с самого его образования. Но хотя наличие этих предметов в коллекции минералов и выглядит как “естественное” и “само собой разумеющееся,” очевидно, что любой предмет, попадая в коллекцию, меняется - он наделяется новыми значениями, подчиняясь особой логике коллекции, переозначивается. ${ }^{13}$

Система минералогии как форма каталога Минерального кабинета превращала в камень любую вещь, попавшую в коллекцию, одна из характерных особенностей почти любого минералогического собрания: изделия из камня в коллекции обозначаются не как вещи, а как минералы. Первая графа любого каталога с XVIII в. и до сегодняшнего дня - это всегда точное научное название минерала (несмотря даже на исчезновение к концу XVIII в. минеральных каталогов как жанра). Не шкатулка и не ваза, не кольцо и не драгоценность, не мозаика и не огранка, всегда только минерал: алмаз, сердолик, аметист, агальматолит, нефрит. Однако само содержание этих “всегда минералогических” обозначений предметов коллекции идет ли речь о необработанном образце минерала, или изделии из него, менялось в истории коллекции, и анализ описаний мозаик позволяет показать одно из направлений этих изменений.

\footnotetext{
" ПДК - коллекция поделочных и драгоценных камней, в состав которой обычно наряду с “сырыми” образцами входят минералы, обработанные человеком, а также произведения камнерезного и ювелирного искусства. Сейчас такие коллекции ПДК являются непременной составляющей почти любого музея геолого-минералогического профиля.

12 "В 1925 г. в связи с 20о-летним юбилеем Академии наук, торжественно отмечавшимся советским народом, музейные фонды значительно увеличились за счет отдельных экземпляров и коллекций поделочных и драгоценных камней и изделий из камня, отчасти монументальных. Эти материалы, представляющие большую художественную и познавательную ценность, были переданы из Государственных фондов дворцового имущества, а также из дублетных фондов Эрмитажа." См.: Г. П. Барсанов, В. А. Корнетова, "История развития Минералогического музея им. А. Е. Ферсмана АН СССР за 270 лет (1716-1986)," Старейшие минералогические музеи СССР. Очерки по истории геологических знаний, вып. 25 (Москва: Наука. 1989), 31 (G. P. Barsanov, V. A. Kornetova, "Istoriia razvitiia Mineralogicheskogo muzeia im. A. E. Fersmana AN SSSR za 270 let (1716-1986)," Stareishie mineralogicheskie muzei SSSR. Ocherki po istorii geologicheskikh znaniii, vyp. 25 (Moscow: Nauka, 1989), 31). О создании выставки ПДК в музее см. также А. А. Годовиков, “Основные хронологические даты в истории Минералогического музея им. А. Е. Ферсмана АН СССР,” Старейшие минералогические музеи СССР, 59. (A. A. Godovikov, "Osnovnye khronologicheskie daty v istorii Mineralogicheskogo muzeia im. A. E. Fersmana AN SSSR,” Stareishie mineralogicheskie muzei SSSR, 59).

${ }^{13}$ S. Stewart, "The Collection, Paradise of Consumption," in On Longing: Narratives of the Miniature, the Gigantic, the Souvenir, the Collection (Durham, NC: Duke University Press, 1993).
} 


\section{Мозаики и их описание в каталогах}

Кратко обозначим пункты атрибуции плакеток флорентийской мозаики ${ }^{14}$ по Минеральному каталогу Кунсткамеры 1745 г. ${ }^{15}$ Минеральный каталог Кунсткамеры 1745 г. $^{16}$ - это первое описание коллекции Минерального кабинета, и одно из первых академических сочинений по минералогии в России. ${ }^{17}$ Он был готов в конце 1741 года и в 1745 году опубликован в составе общего каталога всех коллекций Кунсткамеры (Musei Imperialis Petropolitani Vol. I-II. 1741-1745). Общий каталог собрания Кунсткамеры состоял из двух томов, и описывал анатомическую, ботаническую, минеральную, нумизматическую коллекции, собрание художественных предметов и редкостей, а также и другие коллекции Кунсткамеры; Минеральный каталог входил в третью часть его первого тома. Описание минералов в Минеральном каталоге 1745 г. предварялось заголовком: "Catalogus minerarum. Cam. PP. QQ. RR. SCRIN. 1 - 16.” Согласно каталогу, мраморы располагались в 7 шкафу (SCRIN. VII), а сам Минеральный кабинет в 1741-1745 гг. занимал три зала (“камеры”) Кунсткамеры - PP, QQ, RR.

Помимо правки уже написанных статей (Иоганном Гмелиным были описаны рудные минералы, соли и земли), Ломоносов полностью составил разделы “смол," “янтарей,” “материй, обращенных в камни,” “камней простых и больших,” “мраморов,” “горных хрусталей” и “камней дорогих"18 - то есть описания мозаик составил именно М. В. Ломоносов.

\footnotetext{
${ }^{14}$ Флорентийская мозаика (или согласно ее историческому наименованию - pietra dura) получила широкое распространение в Италии в эпоху Возрождения. Эту технику условно можно назвать “инкрустацией камнем." Подобно инкрустации деревом (маркетри), флорентийская мозаика укладывает разноцветные пластинки поделочных камней на плоскости, вплотную друг к другу согласно задуманному рисунку. В отличие от инкрустации, в pietra dura нет вмещающего материала, кусочки камня просто наклеиваются на каменную основу. В отличие от мозаики "римской," где мелкие тессеры (плоские квадратные плиточки камня) все примерно одинаковы по размеру и форме, и "рисуют," подобно мелким мазкам живописца, в pietra dura вплотную друг к другу компонуются пластины камня самых разных размеров и форм. Часто контуры пластинок повторяют целиком абрис какого-либо предмета, или детали изображения; мозаичисты учитывают и используют естественный узор камня. Расцвет мозаики обычно связывают с Флоренцией, где в 1588 г. Фердинанд I Медичи, великий герцог Тосканы, сновал мозаичную мастерскую. Такой вид мозаики оказался настолько популярен, что начиная с XVII века мастерские pietra dura появились и начали развиваться и в других европейских странах.

${ }^{15}$ В данной статье не повторяются все детали атрибуции, проведенной в 2010 г. (об этом подробно см. Новгородова, “Флорентийская мозаика," 131-164 (Novgorodova, "Florentiiskaia mozaika," 131-164).

16 "Catalogus minerarum," Musei Imperialis Petropolitani, vol. 1, ps. 3, Qua continentur res naturalis ex regno minerali (St. Petersburg: Typis Academiae scientiarum Petropolitanae, 1745). О составителях Минерального каталога Кунсткамеры 1745 г. и их работе подробно см. А. Н. Анфертьева, "Иоганн Георг Гмелин," Словарь языка М. В. Ломоносова, вып. 5, 77-88 (A. N. Anfert'eva, "Iogann Georg Gmelin,” Slovar' iazyka M. V. Lomonosova, vyp. 5, 77-88). Анфертьева, "Иоганн Амман," Словарь-справочник “Минералогия М. В. Ломоносова," 89-96 (Anfer'teva, "Iogann Amman," Slovar'-spravochnik “Mineralogiia M. V. Lomonosova," 89-96). С. С. Волков, "Михаил Васильевич Ломоносов," Словарь-справочник "Минералогия М. В. Ломоносова," 97-102 (S. S. Volkov, "Mikhail Vasil'evich Lomonosov," Slovar'spravochnik "Mineralogiia M. V. Lomonosova," 97-102).

${ }^{17}$ C. С. Волков, "Михаил Васильевич Ломоносов," 50 (S. S. Volkov, "Mikhail Vasil'evich Lomonosov," 50).

${ }_{18}$ А. И. Андреев, И. И. Шафрановский, “Примечания,” М. В. Ломоносов, Минеральный каталог, Полное собрание сочинений, т. 5 (Москва-Ленинград: Изд. АН СССР, 1954), 654 (А. I. Andreev, I. I. Shafranovskii, "Primechaniia," M. V. Lomonosov, Mineral'nyi katalog, Polnoe sobranie sochinenii, t. 5 (Moscow-Leningrad: Izd. AN SSSR, 1954), 654).
} 


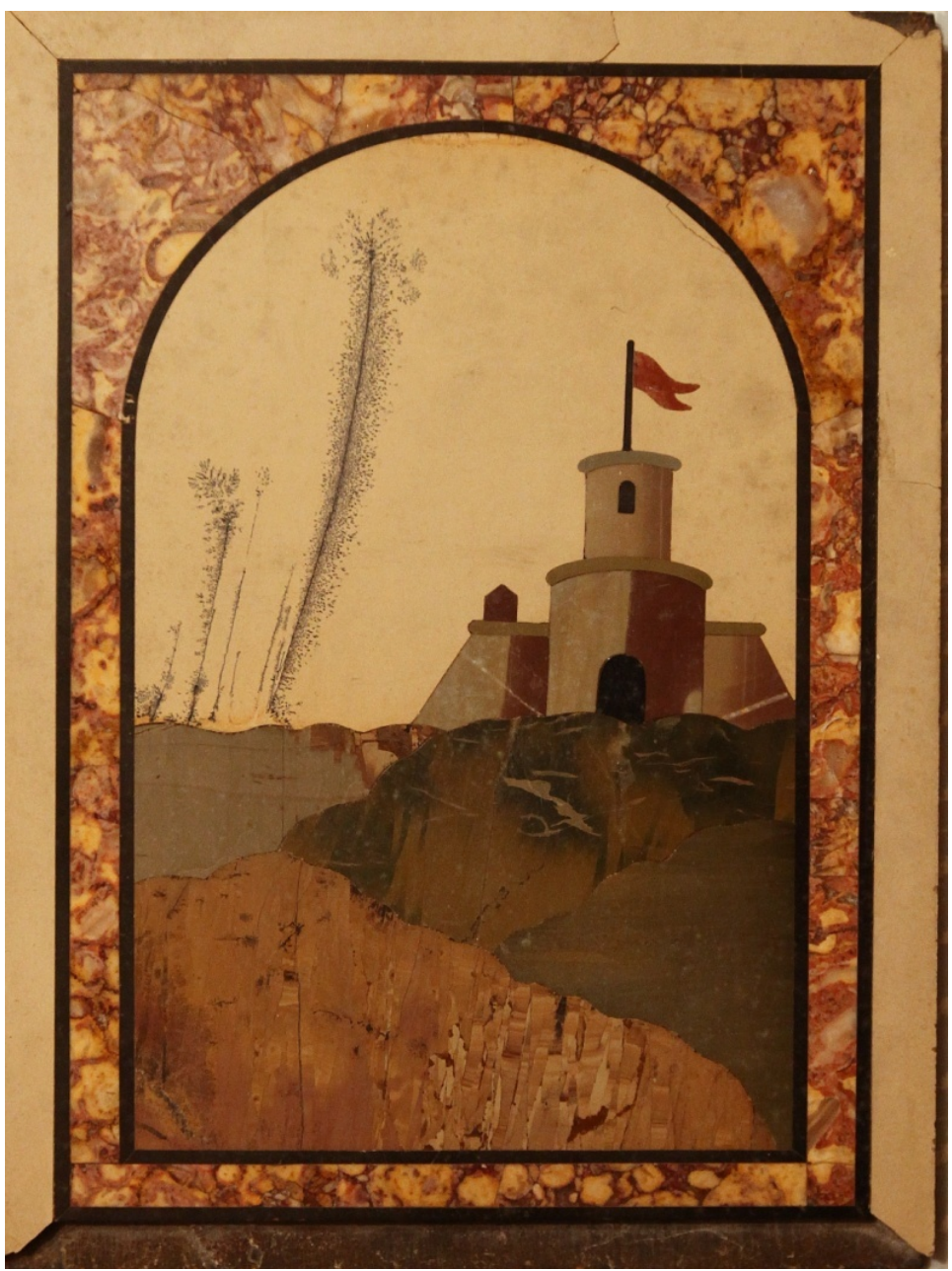

Фигура 2. "Плита четверобочная, длиною около фута, в ширину меньше, на которой мусиею изображена башня с флагом, неподалеку от нее вставлены дерева, в дентрите изображенные" (Ломоносов 1954, 194). Плакетка флорентийской мозаики из фондов Минералогического музея им. А. Е. Ферсмана РАН (ПДК-657) и ее описание в Минеральном каталоге Кунсткамеры 1745 г.

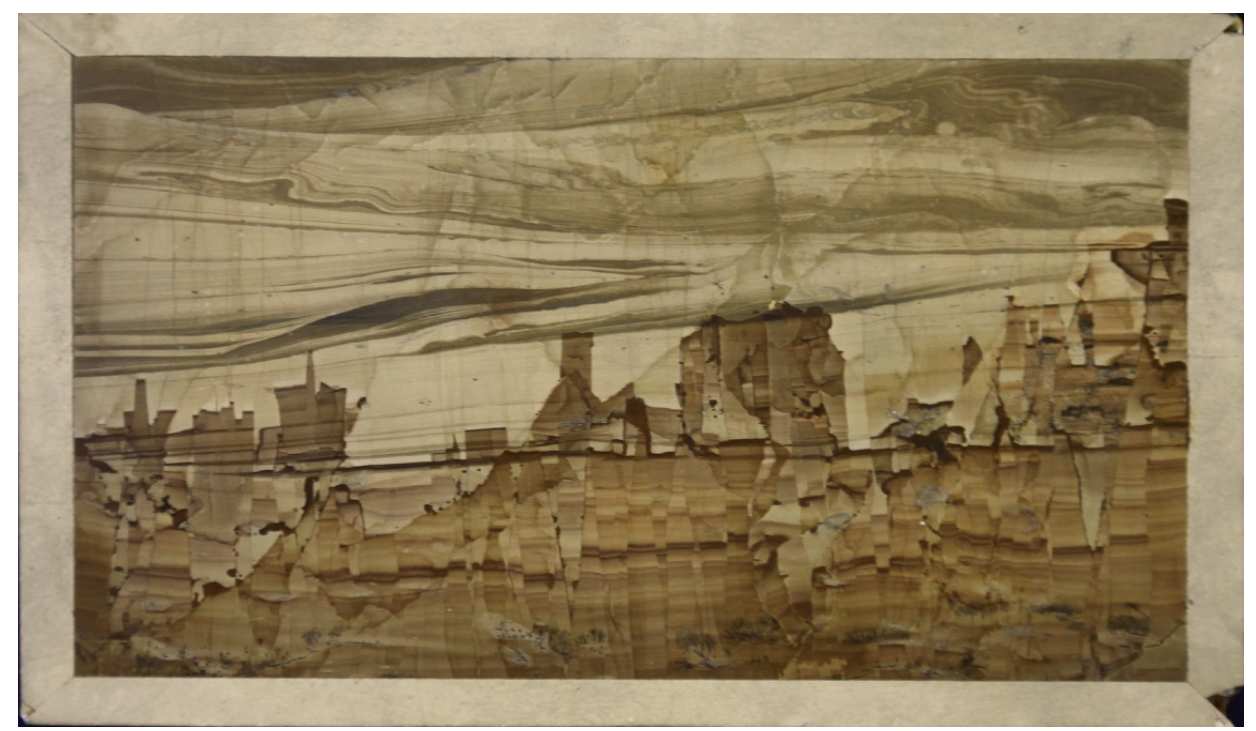

Фигура 3. "Плитка четвероугольная, продолговатая, из флоренского мрамора высечена, на которой каменные горы, обрушившиеся здания и облака в их натуральном виде представлены, цвету темножелтого. К краям сей плитки приклеены тоненькие дощечки белого мармора наподобие рамок. Она длиною больше половины фута, а шириною почти равна" (Ломоносов 1954, 193-194). 
Плакетка флорентийской мозаики из руинного мрамора из фондов Минералогического музея им. А. Е. Ферсмана РАН (инв. ПДК-2095) и ее описание в Минеральном каталоге Кунсткамеры 1745 г.

В таблицах $(1,2)$ помещены фотографии мозаичных плакеток из фондов Минералогического музея им. А. Е. Ферсмана РАН и описания Минерального каталога 1745 г.; раздел “Мраморы” начинается описанием плакеток флорентийского $^{19}$ мрамора (№№ 1-18); плакетки флорентийской мозаики с тосканскими пейзажами описаны далее в том же разделе “Мраморы” (№№19-31), $(\mathrm{Tab} .1,2)$. Обращает на себя внимание яркая образность и наглядность описаний М. В. Ломоносова, позволяющая по ним без труда узнать предметы (Фигуры 2, 3). Указание М. В. Ломоносова на “башню с флагом" и “деревья в дентрите” невозможно пропустить человеку, знающему фонды Минералогического музея им. Ферсмана.
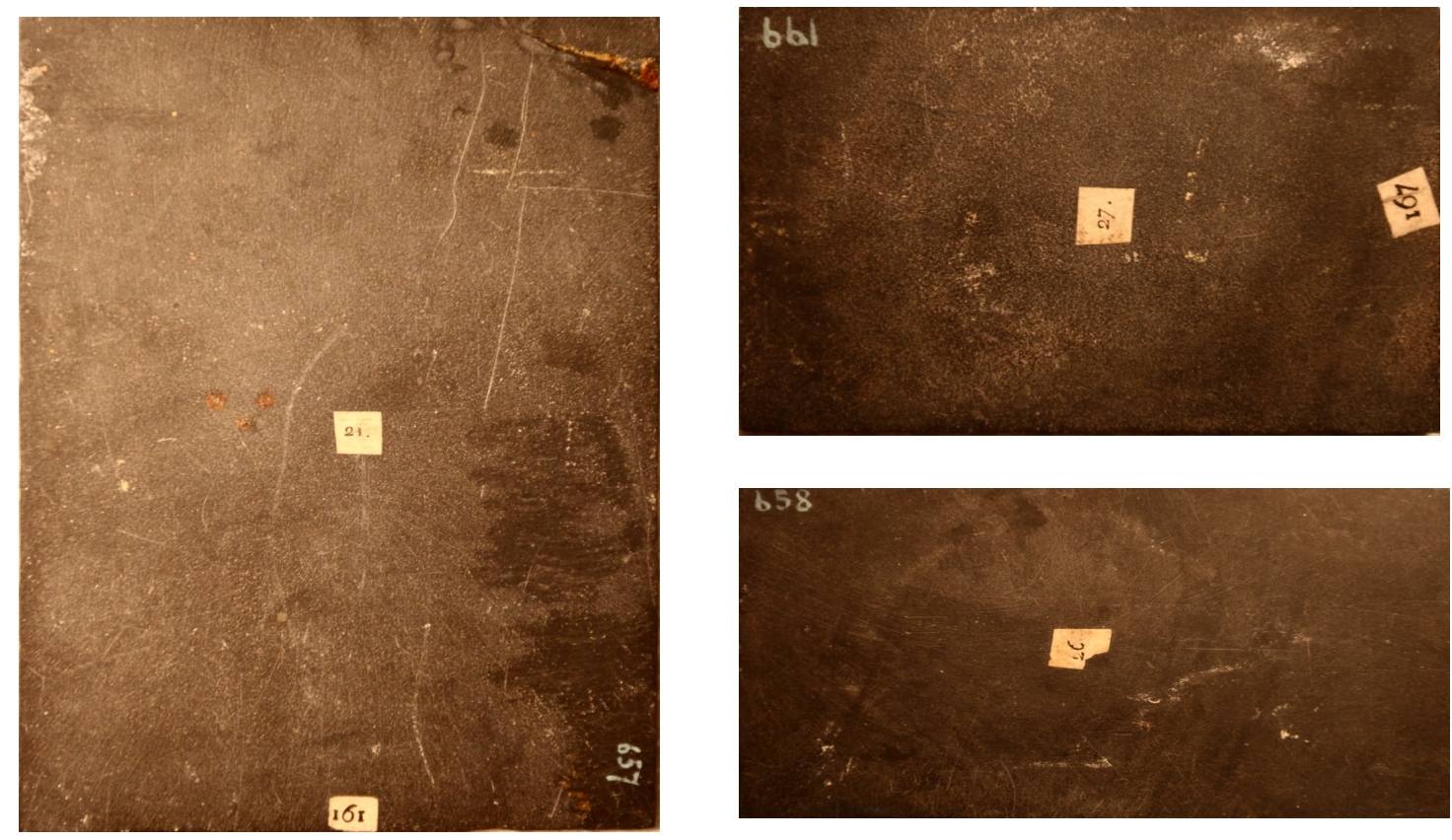

Фигура 4. Инвентарные номера, сохранившиеся на обороте мозаичных плиток: 21, 26, 27 Минерального каталога Гмелина-Аммана-Ломоносова (1745 г.); 161, 167 - Каталога Георги-РенованцаЗуева (1786-89 гг.), 657, 661, 658 - современного Минералогического музея им. А. Е. Ферсмана РАН.

Несколько мозаичных плакеток с тосканскими пейзажами частично сохранили нумерацию Минерального каталога Кунсткамеры 1745 г.: №№ 21 (Башня с красным флагом), 26 и 27, (Фигура 4, также см. графу с номерами в Таблице 1). На двух образцах сохранились три инвентарных номера: самые ранние, первые по порядку это номера Минерального каталога 1745 г., поздние - номера записи современной инвентарной книги музея. Средние же номера (№№ 161, 167) - это записи в каталоге Георги-Ренованца (1786-89 гг.). В каталоге Георги-Ренованца они описаны столь лаконично, что будь в нашем распоряжении один этот источник, идентификация образцов была бы невозможна: "161 ad 171. Marmor dendricitum cum figuris mosaicis. J”2о (Мрамор дендритовый с мозаичными изображениями).

19 В современной терминологии эта декоративная разновидность мрамора известна как "руинный мрамор."

${ }^{20}$ I. G. Georgi, "Catalogus Mineralium Musaei Academiae Scientarum Imperialis, methodo Wallerii digestus. Anno MDCCLXXXVIII,” ПФА РАН, p-д I, оп. 122, №8, л. 3 об. (PFA RAN, r-d, op. 122, nо. 8, 1. 3 ob.). 
Также в Каталоге Георги-Ренованца по соседству, под №№ 146-153, упоминаются образцы marmor pictorium - “живописного” флорентийского мрамора ${ }^{21}$ (вполне вероятно, того же самого, что и в Минеральном каталоге 1745 г.: флорентийского с природным рисунком, напоминающим руины - однако точно этого нельзя утверждать). Эти описания также могли относиться к рассматриваемым образцам, тем более, что Георги и здесь поставил значок “Ј," отсылающий к Минеральному каталогу 1745 г.). ${ }^{22}$ Также обратим внимание на то, что в Каталоге Георги не описаны сами коллекционные образцы, только материал - мы не знаем, обработанный ли это мрамор или куски. Только о мраморе в деревянной рамке (tendiculis ligneis circumdatis) мы можем догадываться, что это была мозаичная плакетка или, во всяком случае, плоская плитка с прямыми краями.

Разница в подходах к описаниям предметов коллекции Минерального кабинета, которую демонстрируют минеральные каталоги 1745 г. и 1786-89 гг., а также тенденция к большей краткости описаний, видна и в Каталоге Лемана (1760 г.), в нем невозможно найти и следов наших мозаичных плакеток: либо они были в это время перемещены из коллекции, а к моменту составления каталога ГеоргиРеноваца возвращены, либо по-другому описаны. В Каталоге Лемана есть описания некоторых “пейзажных мраморов," которые могли бы относиться к нашим образцам, однако они предельно лаконичны: “95-10о. Marmora varium in modum natura picta”23 (95-10о. Мраморы разные, как разрисованные природой).

Дальнейший поиск записей о мозаичных плакетках в каталогах Минерального кабинета Кунсткамеры позволяет добавить к имеющимся упоминания о флорентийском мраморе из Каталога частной коллекции академика Товия Ловица, поступившей в Минеральный кабинет в 1805 г. $^{24}$ : “1.2. Флорентийские мраморы.” 25 Как видим, в данном случае это уже только название двух образцов горной породы под инвентарными №№ 1,2, - без каких-либо уточнений или описаний. Мы не найдем подробных описаний и в более поздних каталогах Минерального кабинета,

\footnotetext{
${ }^{21}$ Здесь и далее разбираются и цитируются следующие записи Каталога Георги-Ренованца: “172 ad 189. Marmor pictorium florentinium. J. 190. 191. 192. Marmor pictor[ium] florentin[um] tendiculis ligneis circumdati[s]. J", (Ibid, л. 3 об.).

22 Иоганн Георги ввел в систему каталога коллекции Минерального кабинета Кунсткамеры специальную графу, в которой ставил ссылки на описания того или иного образцов в более ранних каталогах, если таковые имелись. Перечень и "расшифровка" буквенных знаков помещена им в начале каталога. См.: I. G. Georgi, Index Lithophylacei exotici Musei Academiae Scientiarum Petropolitanae. Anпо MDCСLXXXIX, ПФА АРАН, p-д I, оп. 122, №8 ${ }^{\text {a }}$ л. 2 об. (PFA ARAN, r-d I, op. 122, nо. 8, 1. 2 оb.). Заметим, что обозначение "J" сначала было отнесено к Минеральному каталогу 1745 г. (J. Musei Imperialii petropolitani. Res naturalei ex Rego minerali. g. 1745), но затем эта надпись была зачеркнута и исправлена на другую: Index Conchyliorum et Gemmarum Scriptus. Мы не можем идентифицировать данный источник (вероятно, более ранний каталог или опись предметов, чем Минеральный каталог Кунсткамеры 1745 г.), однако номер 161 в Каталоге Георги-Ренованца и на обороте "Мозаики с красным флагом," ясно описанной Ломоносовым, дает нам уверенные основания для трактовки обозначения “J” как относящегося (в том числе) и к описаниям Минерального каталога 1745 г.

${ }^{23}$ Lehmann's Catalog. Neueres Exemplar, л. 40.

24 Летопись Российской Академии наук, т. II, 1803-186o (Санкт-Петербург: Наука, 2002), 32 (Letopis' Rossiiskoi Akademii nauk, T. II, 1803-186o (St. Petersburg: Nauka, 2002), 32).

25 Роспись собранию изкопаемых тел покойнаго Господина Академика Ловица, Архив Минералогического музея им. А. Е. Ферсмана РАН, дело №3, л. 13 (Rospis' sobraniiu izkopaemykh tel pokoinago Gospodina Akademika Lovitsa, Arkhiv Mineralogicheskogo muzeia im. A. E. Fersmana RAN, delo no. 3, 1. 13).
} 
составленных опытным минералогом и основоположником русской минералогии В. М. Севергиным, одобренных и отправленных в печать Академией наук. ${ }^{26}$

С более ранним по времени каталогом - Музея Готтвальда (1714 г.), ${ }^{27}$ чье минералогическое собрание дало начало Минеральному кабинету Кунсткамеры, ${ }^{28}$ описания Минерального каталога 1745 г. имеют значительно больше общих черт. В отношении флорентийского (руинного) мрамора, с известными оговорками мы можем указать на возможный источник их поступления, в каталоге Музея Кристофа Готтвальда имеется запись, во многих деталях совпадающая с описанием М. Ломоносова: "Scrinium III, Capsula XXXIII, 28. Tabulae ex marmore Florentino arbusculas et civitatum ruinas repraesentantes, quarum quaedam lineis quadratis inclusa" (Шкаф III, Ящик XXXIII, Двадцать восемь табличек из флорентийского мрамора, изображающие деревца и развалины городов, некоторые из них заключены в квадратные линии). ${ }^{29}$

Сравнивая этот текст с описанием М. В. Ломоносова в Минеральном каталоге, можно с очень большой осторожностью предположить, что речь идет об одних и тех же образцах руинного мрамора и, возможно, Ломоносов при описании этих образцов сверялся с текстом каталога Museum Gottwaldianum(известно, что составители Минерального каталога 1745 г. имели доступ к каталогам Музея Готтвальда). ${ }^{30}$ Вместе с тем, при более внимательном исследовании мы обнаружим, что, по-видимому, в описаниях М. Ломоносова мы имеем дело не со случайным сходством, а со стандартом, практически шаблоном.

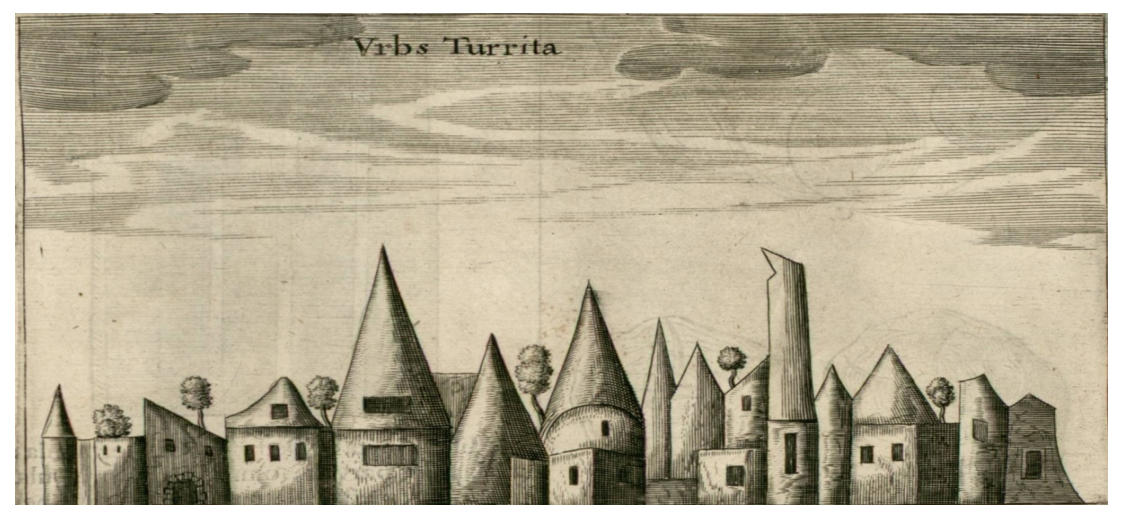

\footnotetext{
${ }^{26}$ Севергин, “Обозрение Минерального кабинета," 3-115 (Severgin, “Obozrenie Mineral'nogo kabineta," 3-115). [В. М. Севергин], Краткая опись Минеральному кабинету Императорской академии Наук, по новому онаго расположению в 1820 году (Санкт-Петербург: При Императорской академии наук, 1821), 3-115 ([V. M. Severgin], Kratkaia opis' Mineral'nomu kabinetu Imperatorskoi akademii Nauk, po novomu onago raspolozheniiu v 1820 godu (St. Petersburg: Pri Imperatorskoi akademii nauk, 1821), 3-115).

${ }^{27}$ Christoph Gottwald, Musaeum Gottwaldianum (Gdansk, 1714). Без пагинации.

${ }^{28}$ Подробно о Музее Готтвальда, его каталогах и обстоятельствах покупки коллекции минералов в Кунсткамеру см. Д. Д. Новгородова, “От Музея Готтвальда к Минеральному каталогу Кунсткамеры,” Н. Н. Казанский (отв. ред.), Индоевропейское языкознание и классическая филология - XVII (СанктПетербург: Наука, 2013), 636-653 (D. D. Novgorodova, "Ot Muzeia Gottwal'da k Mineral'nomu katalogu Kunstkamery," N. N. Kazanskii (otv. red.), Indoevropeiskoe iazykoznanie i klassicheskaia filologiia - XVII (St. Petersburg: Nauka, 2013), 636-653).

${ }^{29}$ Gottwald, Musaeum Gottwaldianum (Gdansk, 1714). Аукционный каталог Музея Готтвальда издан без пагинации, поэтому для удобства поиска в основном тексте приведены номера шкафа и ящика, указанные в каталожных описаниях.

${ }^{30}$ Новгородова, “От Музея Готтвальда," 646 (Novogorodova, “Ot Muzeia Gottval'da," 646).
} 


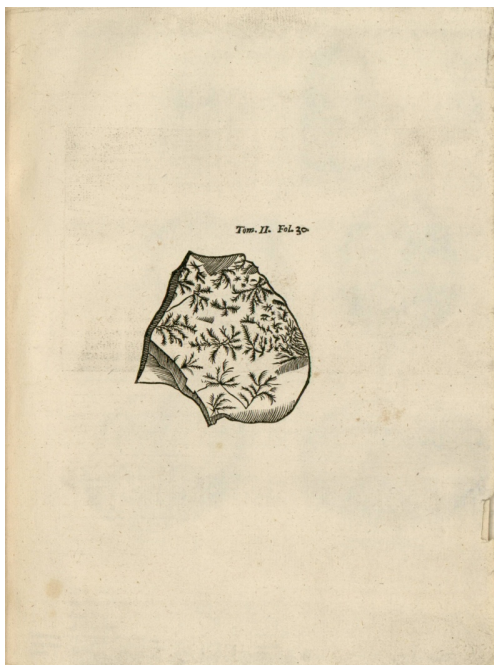

Фигура 5. Зарисовки флорентийского (руинного) мрамора и “дентрита" в “Подземном Мире” Кирхера. ${ }^{31}$

Трудно сказать, когда впервые был описан руинный мрамор. Одни исследователи отдают эту честь знаменитому ученому-энциклопедисту Афанасию Кирхеру, ${ }^{32}$ ссылаясь на его работу “Подземный мир” (фигура 5).33 Другие утверждают, что руинный мрамор был известен еще в II тысячелетии до нашей эры, а в 1597 г. ученый монах Агостино дель Риччио описал его в своей “Истории камня" (Istoria delle pietre), особенно подчеркивая любовь к этому камню во Флоренции. ${ }^{34}$ Если мы посмотрим на описания флорентийского мрамора в каталогах собраний редкостей XVII-XVIII вв., а к тому времени этот “диковинный камень был весьма популярен среди коллекционеров," 35 то найдем, что везде он указан с непременным упоминанием изображений на нем руин, городов и домов, деревьев, облаков и т.д. будто бы нарисованных на его поверхности природой.

Иными словами, молодой Ломоносов, описывая флорентийский мрамор, мог сверяться как с записями Каталога Коллекции Готтвальда, так и с любым другим описанием флорентийского мрамора в современных ему научных трудах - все они были примерно одинаковы, как сейчас в любых “Минералогиях" минералы описываются более ли менее одинаковым образом. Однако позже этот стандарт сменился.

\footnotetext{
${ }^{31}$ A. Kircher, Mundus subterraneus, vol. II (Amsterdam: Joannem Jansonium \& Elizeum Weyerstraten, 1664), 30.

${ }^{32}$ M. Serra, et al., "Petrographic features, genesis and provenance of Pietra Paesina collections of the Regional Museum of Natural Sciences of Turin, Italy," Periodico di Mineralogia. An International Journal of Mineralogy, Crystallography, Geochemistry, Ore Deposits, Petrology, Volcanology and applied topics on Environment, Archeometry and Cultural Heritage, vol. LXXIX (December 2010), 96.

${ }^{33}$ Kircher, Mundus subterraneus, vol. II.

${ }^{34}$ A. Del Riccio, Istoria delle Pietre [1597], reprint R. Gnoli and A. Sironi (eds.) (Turin: Archivi di arte decorative, 1996), 122-3. Цит. по W. Koeppe, A. Giusti, Art of the Royal Court: Treasures in Pietre Dure from the Palaces of Europe (New York: Metropolitan Museum of Art, 2008), 159. Выдающий труд Агостино дель Риччио "История камня" так и не был издан вплоть до 1976 г. (фотокопии рукописи), поэтому едва ли мог оказать особенное влияние на европейскую научную мысль своего времени, однако упоминание в нем флорентийского мрамора однозначно показывает, что этот камень было хорошо известен и использовался уже в XVI в.

35 Знаменитый кабинет Оле Ворма (после смерти коллекционера он вошел в состав Датской королевской кунсткамеры, которую не раз посещал Петр Первый) мог похвастаться объемным изделием из руинного мрамора - миниатюрным глобусом. См.: O. Worm, Museum Wormianum (Leiden: Ex officina Elseviriorum, Acad. Typograph, 1655), 44.
} 
Отсутствие развернутых описаний в каталогах коллекции Минерального становится нормой к XIX в.: о минералах больше не рассказывается как в учебнике минералогии, они просто называются. Описание флорентийского мрамора как мрамора с природным изображением руин трансформируется в само название: флорентийский (или руинный) мрамор - так они обозначены и в современной инвентарной книге музея.

\section{Мозаики как образные камни}

Между двумя обозначениями одного и того же камня в каталогах: “флорентийский мрамор, изображающий руины,” и “флорентийский (или руинный) мрамор” существует семантическое различие - эти обозначения отсылают к разным нарративам и, соответственно, наделяют предметы (флорентийские мозаики) разными значениями.

Обратим внимание на элементы описания мозаичных плакеток в Минеральном каталоге 1745 г., акцентированные в тексте, составляющие ядро описания (см. Таблицы 1, 2). Во-первых, эти ключевые элементы относятся не к самому предмету мозаичной плакетке, а всегда к материалу, из которого выполнены мозаики мрамору (флорентийскому или “дентриту”); во-вторых, главным атрибутом мрамора выступает то, что он что-то изображает (деревья - если это “дентрит," 6 и и руины и развалины - если это флорентийский мрамор). Это его свойство указано практически в каждой каталожной записи, например: “Плитка [...] из флоренского мрамора высечена, на которой каменные горы, обрушившиеся здания и облака в их натуральном виде представлены”;37 “Плита [...] на которой мусиею ${ }^{38}$ изображена башня с флагом, неподалеку от нее вставлены дерева, в дентрите изображенные”; “Девять плиток [...] где мусиею изображены разные строения с деревами."4о

Из этих примеров также очевидно, что “изображение” бывает либо природным (деревья в дентрите или горы, разрушенные здания и облака, видимые на поверхности флорентийского мрамора), либо сделанным человеком, художественным, - выполненным в технике мозаики, когда рядом с марганцевым включением в форме деревца художник помещает “свое” деревце - мозаичное; $4^{11}$ причем Ломоносов никак не противопоставляет эти два вида “искусства,” а перечисляет их через запятую как равноправные.

\footnotetext{
36 “Дентрит” современный минералог естественно прочитывает как искаженное “дендрит” - название для формы минеральных включений в горных породах, преимущественно марганцевых включений в известняках - по внешнему виду они напоминают деревца (на мозаичных плакетках с тосканскими пейзажами хорошо видны такие "ветвеподобные" включения темного цвета, (Фигура 2).

${ }^{37}$ В латинском тексте, ad vivum depicta: См.: М. В. Ломоносов, Труды по минералогии, металлургии и горному делу 1741-1763 г2., т. 5. Полное собрание сочинений (Москва-Ленинград: Издательство Академии наук СССР, 1954), 7-241 (M. V. Lomonosov, Trudy po mineralogii metallurgii i gornomu delu 17411763 gg., t. 5 Polnoe sobranie sochinenii (Moscow-Leningrad: Izdatel'stvo Akademii nauk SSSR, 1954), 8-241). Здесь и далее - курсив мой. Целиком все описания флорентийского мрамора см. в Таблице 2. Там же, 193. (Tam zhe, 193).

${ }^{8}$ T.е. мозаикой. В исходном латинском тексте Минерального каталога стоит mosaic: “in qua opere mosaico turris cum aplustri repraesentatur" (см. описания №№ 22, 26).

39 "aedificia varia, adstantibus ex dentrite arbusculis, opere mosaico depicta sunt" (там же, 26) (Tam zhe, 26).

${ }^{40}$ Там же, 194 (Tam zhe, 194).

${ }^{41}$ В русском тексте “мусия” - это мозаика (ср. в латинском, “толаiсо”).
} 
Как было показано, фиксация М. В. Ломоносовым в научном описании предметов из коллекции Минерального кабинета Кунсткамеры “изображенных" и “нарисованных,” “будто живых” пейзажей на поверхности камня - это не поэтическая метафора в описаниях конкретных образцов, а точная передача принятого научного обозначения конкретной горной породы. Но кроме того, изучение современных М. В. Ломоносову научных источников позволяет увидеть здесь ясное указание на то, что данные мраморы обладают свойствами особых минеральных образований, хорошо известных в системе минералогического знания XVIII в. и полностью вытесненных из него к началу XIX в. - фигурных камней. “Фигурные," или камни с “фигурами” в российской минералогии XVIII в. - это как раз камни, которые что-то “изображают” (или на что-то похожи). Также они еще назывались “образные камни” - т.е. камни с некоторыми образами. ${ }^{42}$

В большинстве минералогических систематик XVIII в. фигурные камни вместе с камнями из внутренностей человека и животных, слепками, отпечатками и окаменелостями обычно объединялись в одну группу или соседствовали (например, И. Леман рассматривает их в своей Минералогии в одной группе - "Особливо изображенных камней”). ${ }^{43}$ В Минеральном каталоге 1745 г. “дентрит” также встречается в двух разделах каталога: "Мраморы” и “Материи, в камень обращенные” - это второе свидетельство о связи данной разновидности мрамора с фигурными камнями в XVIII в.

Иными словами, мозаичные плакетки были “означены” (несли значение) в каталожных описаниях Минерального кабинета не как произведения декоративноприкладного искусства, и даже не как декоративный камень, сырье для таких произведений, а как фигурные камни - через материал, из которого они сделаны, флорентийский мрамор и или дентрит. В пользу такой интерпретации говорит также тот факт, что в их описаниях не были упомянуты никакие другие материалы, - ни черный пробирный камень основы, ни разновидности мрамора, которые были использованы - хотя нет сомнений в том, что они могли быть упомянуты, если бы существовала такая задача. Например, непосредственно после описаний мозаичных плакеток в Минеральном каталоге 1745 г. помещены великолепные и подробные описания образцов различных разновидностей мрамора, к каждой из которых приведено их итальянское название, - в том числе описан и знаменитый красноватый мрамор “брокачелло ди Спания,” из которого выполнены детали в мозаиках с тосканскими пейзажами. ${ }^{44}$ Поэтому, чтобы понять каким значением обладали данные мозаичные плакетки в коллекции Минерального кабинета, почему они туда попали и к каким научным и культурным сюжетам отсылали нужно знать, что такое фигурные, или образные, камни.

\footnotetext{
${ }^{42}$ Известный минералог Иоганн Леман приводит общепринятое определение образным камням в своей Минералогии (немецкое издание 1758 г.): “Образные камни представляют либо во всем своем виде тело из царства ростений или животных, или представляется на них только очертание оных. Часто называют их также игралищем естества, и представляют то небесные тела, яко солнцы, месяцы, звезды, облака и проч. или зверей и их части, ростения, деревья, ландшафты, писмена, разные орудия, математические фигуры и проч. и находятся множество на известковых камнях, марморах, кремнях, агатах, и твердых землях; цветы их разные, то бывают цветы только на верхней плоскости оных, то насквозь камни проходят." См.: И. Г. Леман, Иоганна Готлоба Лемана, Королевского Прусскаго горного советника (Санкт-Петербург: при Имп. акад. наук, 1772), 106 (I. G. Leman, Ioganna Gotloba Lemana, Korolevskogo Prusskago gornogo sovetnika (St. Petersburg: pri Imp. akad. Nauk, 1772), 106).

${ }^{43}$ Там же, 96 (Tam zhe, 96).

${ }^{44}$ Ломоносов, Труды по минералогии, 195 (Lomonosov, Trudy po mineralogii, 195).
} 
Описания в Минеральном каталоге 1745 г. “фигурных камней” (или камней “с фигурами”) - минеральных образцов, напоминающих по форме нечто другое, чем они являются: не камень, а хлеб, младенца, птицу и др. - на первый взгляд представляют собой искрометную игру метафор, однако, как и в случае “флорентийского мрамора, изображающего руины," они лишь точно следуют традиции описания фигурных камней. В Минеральном каталоге раздел "Камни с фигурами,” в частности, содержат образцы, подобные “двойному хлебу,” “спелененному младенцу," “мертвой голове,” “наподобие червей,” “наподобие тайного мужеского уда, с жилами беловатыми," 45 “наподобие пальцев,” “камень, видом похож на ногу," “похож на некоторую часть лягушки или рака,” “яблоко гнилое, или камень круглый, развалившийся, в средине с зубчатыми дорожками”и др.. ${ }^{46}$

В следующем по времени сводном каталоге Минерального кабинета, Лемана (176о г.), также присутствуют различные фигурные камни - иногда описанные с детальными подробностями (как например туфовый камень, представляющий птицу без ног и хвоста), ${ }^{47}$ иногда просто как “камни с фигурами.”

Ко времени появления последнего в XVIII в. сводного каталога Минерального кабинета, Каталога Георги-Ренованца-Зуева (1786-1789 гг.), относится переворот в российском геолого-минералогическом знании - коллекция окаменелостей впервые была отделена от минералогической части и описана в отдельном Каталоге окаменелостей, составленном адъюнктом Зуевым. ${ }^{48}$ Этот каталог может считаться первым российским палеонтологическим сочинением (задолго до оформления палеонтологии как самостоятельной науки). Появление такого каталога настоящий переворот, потому что, хотя окаменелости в минеральных каталогах описывались и раньше, и также обособлялись в отдельную группу, само содержание Каталога Зуева было принципиально другое - в частности, каталог не включал “фигурных камней," их описаний просто не было в каталоге, все эти “камни, похожие на ...” исчезли из коллекции. Не было их и в минералогической части Каталог Георги-Ренованца описывал коллекцию согласно Системе минералогии шведского минералога Юхана Готтшалька Валлерия и, хотя там имелся класс “Камни” (Lapides), однако в отличие от Каталога Лемана, внутри него разделение шло согласно минеральному составу образцов, а их формы (среди которых могли оказаться и более или менее “фигурные”) указывались или нет, но только в качестве характерных кристаллических проявлений, или же в порядке описания габитуса образца. В целом, это следует логике новой, нарождающейся науки, четко определяющей свой предмет и границы - науки минералогии. Выше были приведеные описания мозаик в Каталоге Георги-Ренованца (как раз в разделе Камни), для которых не указана ни их форма, ни размеры, ни даже то, что это не с природный кусок камня, а с произведение декоративно-прикладного искусства мозаичные плакетки.

\section{Мозаики как Lusus Naturae в коллекции Минерального кабинета}

\footnotetext{
${ }^{45}$ Ср. в Каталоге Лемана: “Lapis niger penem cum frenelo exacte referens," Lehmann's Catalog. Neueres Exemplar, л. 51.

${ }^{46}$ Все см. Ломоносов, Труды по минералогии, 218 (Lomonosov, Trudy po mineralogii, 218).

47 "Lapis tephaceus figuram volucris sine pede et cauda repraesentans," Lehmann's Catalog. Neueres Exemplar,. л. 52 об.

${ }^{48}$ Enumeratio fossilium, л. 82-94.
} 
Фигурные камни - отсылка к определенной научной традиции XVII - нач. XVIII вв., восходящей еще к античности, - представлениям об “играющей Природе”: “Греки, внимательные и вдумчивые наблюдатели, не могли не заметить, что природа иногда шалит, что она, подобно ребенку, создает и разрушает многообразные и пестрые сочетания, что она шутит, находит удовольствие в беспорядочном переизбытке. [...] Об “играющей” природе особенно много говорит Плиний: о роскоши и “состязании” цветов весной [...]; о разнообразии формы рогов [...]; о разнообразии ракушек и др. [...]. У Плиния же встречается и выражение varie ludens при описании расцветок цветов [...] Феофраст в своей ботанике, так же как и Аристотель, допускает неисследимое, “играющее” разнообразие природы. [...] Особо ясно “играющая природа” выступает у Посидония из Апамеи. [...] У Гераклита мы встречаем прямое обозначение природы как “играющей”: "Вечность есть дитя играющее, которое расставляет шашки: царство [над миром] принадлежит ребенку” [...] Такого воззрения придерживался не один Гераклит, но и некоторые позднейшие философы." ${ }^{9}$ От Плиния ведет историю концепции играющей Природы и известный историк науки Пола Финдлен в своей статье, анализирующей воздействие этой идеи на развитие научных практик в раннее Новое время. ${ }^{50}$

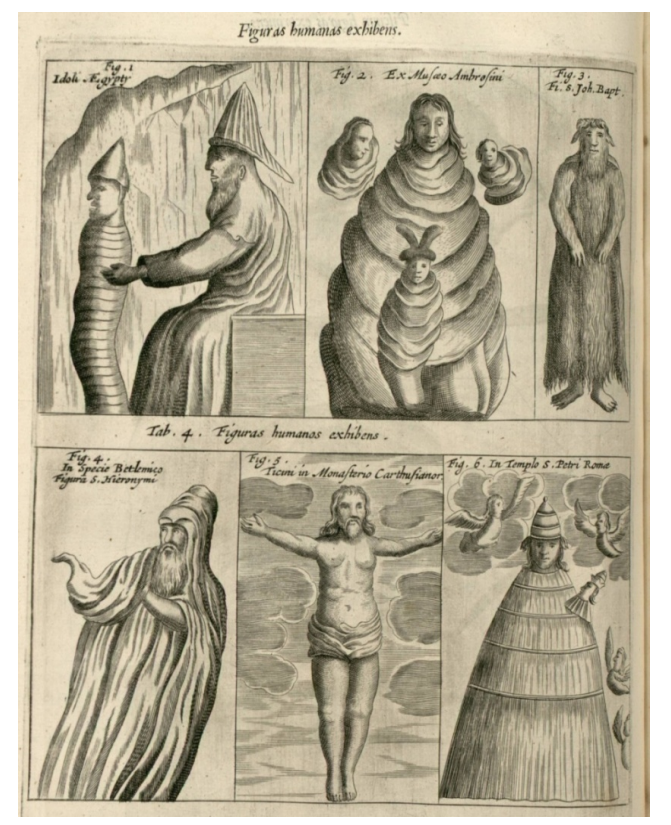

Фигура 6. Изображения различных фигурных камней в “Подземном мире” Кирхера (1664-1665 гг.). ${ }^{51}$

В европейском научном дискурсе XVIII в. “игры” Природы стали предметом оживленной научной полемики, они больше не полагались недоступными человеческому пониманию, исследователи задавались вопросами: почему она играет? что это значит? как у нее получается? О причинах существования “фигурных камней,” камней, которые “что-то изображают,” пишет А. Кирхер в II томе своем геологического сочинения Подземный мир - в главе IX, которая красноречиво называется “De admirandis Naturae pictricis operibus, formis, figures,

49 А. Ф. Лосев, История античной эстетики, том IV. Аристотель и поздняя классика (Харьков: Фолио, 2000), 334 (А. F. Losev, Istoriia antichnoi estetiki, tom IV. Aristotel' i pozdniaia klassika (Khar'kov: Folio, 2000), 334).

$5^{50}$ P. Findlen, "Jokes of Nature and Jokes of Knowledge: The Playfulness of Scientific Discourse in Early Modern Europe," Renaissance Quarterly, 43:2 (Summer, 1990), 296.

${ }^{51}$ Kircher, Mundus subterraneus, vol. II, 36, 31. 
imaginibus quas in lapidibus \& gemmis delineat, eorumque origine \& causas" (O достойных удивления произведениях Природы, формах, фигурах, изображения которых в простых и драгоценных камнях начерчены, об их происхождении и причинах): "Natura ludibunda cum vegetativam sensitivamque facultatem in regno mineralium attingere non posset, fecit quod potuit; id est, cum vitam $\mathcal{E}$ sensum eus dare non posset, saltem Figuram eis indidisse satis esse rata, pictores, imitata, omnium, quae in Mundo continentur, rerum figures ambitioso peniculli magisterio delineasse visa eat." ${ }^{2}$ (Игривая природа так как не может в царстве минералов наделять способностью к жизни и чувствованию, делает что может; то есть, из-за того, что жизнь и чувства им дать не может, по крайней мере даровала им достаточно фигур вместо этого, живописцам подражая всевозможным, которые в Мире содержатся, придавая вещам образы, которые кажутся созданными кистью честолюбивого мастера) (фигура 6).

Хотя сами минералы и не обладают жизнью и чувствами, их Минеральное царство открыто человеку не только вещественно, физически, но и культурно, и экзистенциально: читатель Кирхера в изобилии встретит в его научном сочинении о подземном мире и жизнь, и человеческую культуру: Кирхер описывает не только произведения искусства, созданные любящей пошутить Природой (несмотря на всю игривость созданные, однако, согласно всем правилам современной Кирхеру эстетики), но и подземных жителей - драконов, людей, разных животных; пишет он и о знаках на камнях, литерах.

Попытки понять этот открыто явленный “язык природы” продолжались на протяжении первой половины XVIII в. Однако одновременно с кирхерианским истолкованием причин удивительных природных форм могло быть применено и другое объяснение. Например, в Записках Лондонского королевского общества мы находим статью ботаника Клейна, в которой сообщается о загадочных литерах, найденных в сердцевине ствола букового дерева, и исследуются возможные причины их образования. ${ }^{53}$ Следуя научному канону своего времени, Клейн приводит все известные мнения современных ученых о подобных случаях (упоминая знаменитый экспонат из коллекции Готтвальда - природное изображение распятия на поверхности дерева), ${ }^{54}$ однако здесь примечательно его заключение. Так и не придя к окончательному выводу о причинах удивительного явления, он выражает безусловную уверенность в том, что эти причины существуют (и должны быть рационально познаны человеком), но, однако, и предупреждает о том, что наблюдатель может быть обманут своим воображением: “Тогда как одни, напуганные домовыми с детства, слышат шорох призраков и на большом расстоянии, и видят их прогуливающимися в полдень; другие, обученные исследовать Причины Вещей, объясняют это обманом Зрения и Слуха." Природы начинают отнимать ее “искусства” и “игры,” даже насмехаясь над теми учеными, кто их видит в природных вещах (видит несуществующее, будто призраки

\footnotetext{
${ }^{52}$ Kircher, Mundus subterraneus, vol. II, 30.

${ }^{53}$ J. T. Klein, "An Account of Letters Found in the Middle of a Beech," Philosophical Transactions, vol. 41 (1739-1741), 231-5.

54 Здесь же обратим внимание, что “игры Природы” были не только заметной темой узкого научного дискурса, но и частью повседневной жизни, - как сообщает статья, этот образец подобно художественному украшению был выставлен и хранился в здании Данцигской Ратуши. Cм.: Klein, "An Account of Letters," 234.

55 "Such as were wont to be frighted with Hobgoblins from their Infancy, hear the Rustling of Phantoms a great way off, and see them walk at Noon-day; while others, who have learned to inquire into the Causes of Things, are by those accounted dull of Sight and Hearing." См.: Klein, "An Account of Letters," 235.
} 
и домовых, ослепленный собственным незнанием и неспособностью испытывать суть вещей). Еще яснее выразился Лейбниц в геологическом сочинении Протогея:

Я действительно считаю это шуткой, но не Природы, а человеческой фантазии, которая видит армии в тумане и распознает удары колокола или барабанов в зависимости от того, чего хочет. И многие вещи такого рода, которые выставлены для публики в Пещере Баумана, названные Моисеем или вознесением Христа, и другие изображения на камне, которые вы не смогли бы распознать, не будь вы о них предупреждены. ${ }^{56}$

На всем протяжении XVIII в. разделение этих двух типов игры: Природы (которая может быть познана и объяснена) ${ }^{57}$ и человеческого ума (последнее представляет собой просто фантазии и должны быть отброшены как ненаучные) становится важнейшей проблемой минералогии.

В частности, в связи с фигурными камнями встает научный вопрос о возможности окаменения - и вокруг него возникает нешуточная полемика. Так, в академическом журнале Приложения $к$ Санкт-Петербургским ведомостям, печатавшем развернутые научно-популярные статьи для разъяснения публике тех или иных известий и новостей в газете Санкт-Петербургские ведомости, в нескольких выпусках обсуждалось “Триполитанское известие о превращении города в камень” (“которому однако же мало верят” - сразу пристрастно предупреждала статья). ${ }^{8}$ Само “известие,” в самом деле удивительное, предваряло статью: “оный город есть велик кругловатый, с болшими и малыми улицами, в которых в разных местах мелочные и протчие и протчие купецкие лавки имеются, и во оном великий замок построен; что в городе и за городом были разные, но однакож почитай болшая часть масличные и палмовые деревья, которые все в камени синего и темнопесочнаго цвета превратились; что люди еще так стояли, как они разные свои художнества и рукоделия отправляли, некоторые с штофами, иные с хлебом в руках, а каждый еще как будто при своей работе найден, так, что матери со своими детми у грудей, а жены со своими мужами на постелях лежащие все каменные нашлись; что в оном замке разные ворота и входы были, у которых караул поставлен был, оружие и протазаны из каменья в руках держащие; что в оном замке некоторый человек сам каменной на каменной кровати лежал, а напоследок что

\footnotetext{
${ }^{56}$ G W. Leibniz, Protogaea (Chicago: University of Chicago Press, 2008), 74.

57 Как, например, объясняет минералог Леман: “Такие камни, коих весь вид нечто сему подобное представляет, видом своим часто одолжены единому случаю, например: на сыр похожие камни, суть разного вида, которые водою будучи несены, тем так огладились, что похожими стали на сыр. Колбасный камень, есть твердый камень, который из красной яшмы с белым кварцом или шпатом состоит. Каменные раковые глаза суть разскочившиеся шарики. Окаменелые колосья в Ильменавских шиферных почках по большой части суть ни что иное, как только трусоватый шпат, который в пустотах сих шариков в хрусталь обратился. Того же самого рода есть так же издателями описанныя лица с долгими паруками, и прочия такия вещи, которыя только единое воображение награждает часто великое множество недостаточного. Дождевые камни, колодезный зинтер и сим подобные служат великим множеством естественных игралищ для охотников." См.: Леман, Иоганна Готлоба Лемана, 107 (Leman, Ioganna Gotloba Lemana, 107). Однако тут же замечает: “При сем случае намерен я двумя словами напомянуть, что пахучие камни, например: Фиоловый камень, особливого рода несоставляют, но запах свой получают от растущих на них махов," 107.

58 “Триполитанское известие о превращении города в камень," Исторические, Генеалогические и Географические Примечания в Ведомостях Части: VI (1729), 22-4, VII, 25-8, XII, 45-8 ("Tripolitanskoe izvestie o prevrashchenii goroda v kamen'," Istoricheskie, Genealogicheskie $i$ Geograficheskie Primechaniia $v$ Vedomostiakh, Chasti: VI (1729), 22-4, VII, 25-8, XII, 45-8).
} 
такожде разные звери, а имянно: Верблюды, Быки, Лошади, Ослы, Бараны, и птицы видимы были, все в камень вышеупомянутых цветов превращенные." Современный исследователь, зная Помпеи и Геркуланум, не был бы удивлен - но академики XVIII в. были возмущены и опровергали любую возможность превращения живого в камень: "Учиненное в прошлых примечаниях объявление о превращении целых городов, людей, зверей, и протчего в камень есть натуре и известным нам по ныне правилам оной натуры так зело противно, что оное может быть многим за излишнее покажется, что мы о невероятствии онаго еще нечто при сем сообщаем: однакож хощем мы сие дело еще некоторыми примечаниями вкратце изъяснить." "о Изъяснить “вкратце” не получилось - полемика с читателями, которые приводили многочисленные примеры окаменевших вещей из собраний кунсткамер и кабинетов редкостей, растянулась на несколько номеров журнала: “Вы уничтожаете Триполитанское известие особливо такожде по самому основанию, понеже вы плоть человеческую и звериное мясо ко окаменению занеугодно быть почитаете. Как же разсуждать будете о других сему подобных примерах, окоторых подлинности однакоже так просто сумневаться ненадлежит?"61 Среди известных экспонатов были упомянуты “окамененное дитя, которое в Копенгагене в Кунст каморе имеется," “окамененная человеческая голова из Боннана Музеа Кирхерианского," “имеющаяся в Берлинской Кунст каморе окамененная голова птицы кулика; и окамененной мозг быка, которой в Штокголме пред некоторыми годами найден.” Здесь очевидна функция, которую выполняли кунсткамеры в общественном пространстве своего времени - предоставлять вещественные доказательства тем или иным научным теориям: “Ежелиб вы сказать хотели, что в сем деле какое обманство зависит, и вымысел художника здесь натуре последовал, и оное в подобие натуре таким образом зделал, то надлежалоб на вас всех такой штраф положить, чтоб вы при сем случае сами в Копенгаген путь восприяли, и чрез осмотрение онаго о сем деле подлиннее известились. [...] Все то уничтожить вам невозможно будет, что достоверные свидетели подтверждают." здесь внимание на ответ академиков, в котором игры Природы, фигурные камни, это уже не просто не требующие объяснения и недоступные пониманию игры Природы, а “ложные” свидетельства, которые не могут применяться в качестве доказательств чего бы то ни было, не должны входить в научный дискурс: “Суть ли, мы тогож часа разсуждали, сии все подлинно истинные камени, которые за камени почитаются, или оные токмо каменям от части подобны суть? Неможноли так имянуемое окамененное дитя в Копенгагене более за изсохлое почесть, якоже в протчем многие примеры имеются, что у тех детей, которые в матерней утробе несколко лет остались, плоть так тверда стала, что оная камню подобна быть казалась? можно ли Кирхерианскому кабинету совершенно поверить, в разсуждении того, что оной уже во многих обманствах обличен? Не почитатли Берлинской птицы Кулика голову более за образной камень, которой такой птичьей голове токмо подобен есть, каких ныне не мало имеется, и как мы от других обнадежены, подлинные признаки при оном видеть можно, которые оное подтверждают? А на последок, что до окамененного бычьяго мозга касается, не можноли сказать, что оной подлинным мозгом никогда небывал, но от самого

\footnotetext{
59 Там же (Tam zhe).

6о Там же, ч. VII, 25 (Tam zhe, ch. VII, 25).

${ }^{61}$ Здесь и далее там же, ч. XII, 45-6 (Zdes' i dalee tam zhe, ch. XII, 45-6).

62 Там же, 46 (Tam zhe, 46).
} 
начала своего рождения, яко камень в яме мозга родился?”б3 Играющая Природа постепенно становится Природой, обманывающей человека, сбивающей его с толку и подводящей к ложным научным выводам - и это еще одно значение, которое маркирует развитие и изменение нарратива об Играющей Природе в геологоминералогических науках XVIII в.

Фигурные камни в минералогических коллекциях трактуются то как курьезы, не имеющие никакого научного объяснения, то как доказательство научных теорий, а то и как вредные, “ложные” вещи, научное обращение с которыми требует осторожности и рассудительности. Все эти значения сосуществуют на всем протяжении XVIII в., в каталогах Минерального кабинета XVIII в. мы уже можем встретить описания окаменевших вещей, однако в научном дискурсе устанавливается строгое требование уметь их различать и не смешивать ${ }^{64}$. Так, Ломоносов пишет об окаменелостях: “Представим наконец тела животные окаменелые, которые многих в изумление приводят, так что не могут себя уверить, чтобы они когда-нибудь подлинно животные были, но роскошествующия натуры игранием под оных вод [по-видимому опечатка и должно быть “вид” - Д. Н.] подделаны. Однако те, которые натуру не толь шутливою себе воображают и как Нарцисс не возглашают: “Свирепая, что ты, ах, взору представляешь: Что ложными меня ты видами прельщаешь?”б5

Но истинным признаком животных тел, то есть загорелым маслом через перегонку из окаменелых вещей получаемым, уверясь, признают те за подлинные животные, которые, земным трясением поднявшись со дна морского, после окаменели."

Позже в геолого-минералогических науках появляется специальное понятие “псевдоморфозы” (буквально “ложной формы” - минерального образования, в котором минерал явлен в несвойственной ему форме, “ложной” для него, ${ }^{67}$ которая противоречит его кристаллохимической природе; самый простой пример псевдоморфозы - это окаменелости, однако минерал может также заполнять и любую чужую форму, - другого минерала, например). Словари фиксируют самые ранние появления понятия псевдоморфозы в 30 гг. XIX в., ${ }^{68}$ однако наши исследования показывают, что само явление начинает осознаваться и описываться гораздо раньше. ${ }^{69}$

\footnotetext{
${ }^{63}$ Там же, 47 (Tam zhe, 47 ).

${ }^{64}$ Ср. В. В. Зверева, “Культура естественноисторического знания в раннее Новое время,” Л. П. Репина (ред.) Идеи и люди: интеллектуальная культура Европы в Новое время (Москва: Аквилон, 2014), 96 (V. V. Zvereva, "Kul'tura estestvennoistoricheskogo znaniia v rannee Novoe vremia," L. P. Repina (red.), Idei i liudi: intellektual'naia kul'tura Evropy v Novoe vremia (Moscow: Akvilon, 2014), 96).

${ }_{55}$ Вергилий, Энеида, Кн.1, 407 (Vergilii, Eneida, Kn. 1, 407). Ср.: “Сына вводила зачем, жестокая, обликом

лживым

Ты в заблужденье не раз? Почему ни руку с рукою соединить не дала, ни твой подлинный голос услышать?" Вергилий, Энеида (Москва: Худож. лит., 1979), 147 (Vergilii, Eneida (Moscow: Khudozh. Lit., 1979), 147).

66 Ломоносов, “Слово о рождении металлов от трясения земли. Oratio de generatione metallorum a terrae motu," Труды по минералогии, 322 (Lomonosov, "Slovo o rozhdenii metallov ot triaseniia zemli. Oratio de generatione metallorum a terrae motu," Trudy po mineralogii, 322).

${ }^{67}$ В форме младенца, человеческой головы и т.д. или же даже другого минерала.

68 П. Отоцкий, “Псевдоморфоза," Энциклопедический словарь Брокгауза и Ефрона, т. XXVA (СанктПетербург: Типо-Литография И. А. Ефрона, 1898), 663-4 (P. Ototskii. "Psevdomorfoza," Entsiklopedicheskii slovar' Brokgauza i Efrona, t. XXVA (St. Petersburg: Tipo-Lotografiia I. A. Efrona, 1898), 663-4).

69 Д. Д. Новгородова, “О псевдоморфозах,” Л. О. Зайонц (ред.), Живой камень: от природы к культуре (Москва: Институт мировой культуры МГУ, 2015), 213-4 (D. D. Novgorodova, "O
} 
С некоторой степенью условности можно проследить параллели между меняющимся на протяжении XVIII в. положением фигурных камней в минеральном царстве Природы и положением “монстров” в животном царстве. ${ }^{70}$ Михаэль Хагнер фиксирует такое же сосуществование различных, порой взаимоисключающих значений, которыми монстры наделялись в научном дискурсе XVIII в., и их постепенное изменение в рамках представлений об Игре Природы. ${ }^{71}$ Здесь, однако, представляется необходимым возразить основному тезису М. Хагнера, который задает общую логику его статьи: о некоторых особых "возмущении и угрозе паттернам порядка” Просвещения, ${ }^{72}$ которые монстры создавали своей невообразимой и пугающей монструозностью весь XVIII век. Как убедительно показал Мишель Фуко, ${ }^{73}$ монстры стали “монстрами” лишь к концу XVIII в. (первые признаки этого превращения стали появляться лишь со второй половины XVIII в.), до этого же они гармонично вписывались в культурный ландшафт эпохи, играя в нем роль хотя и хара́ктерную, однако ничуть не экстраординарную. В сложной же вселенной кабинетов редкостей, тем более, монстры занимали не более и не менее “особое” положение, чем другие раритеты, можно сказать, что в каком-то смысле любой предмет коллекции являлся монстром (т.е. вещью любопытной и пригодной для демонстрации в коллекции). ${ }^{74}$ Само обилие Систем Природы в XVIII в. доказывает, что не было никакого единого “порядка Просвещения," а одновременно сосуществовали самые разные порядки, среди которых невозможно выделить один главный. Некоторые “порядки,” установленные в одной области научного знания, в другой - напротив, представляли собой форменные “беспорядки,” вносили лишь хаос (что, однако, не отменяло их права на сосуществования): такова, к примеру, Система Природы Карла Линнея ${ }^{75}$ в применении ее к минералогии. Совершивший переворот в биологических науках, в области минералогии Линней предложил систематику, не пригодную для описания минералов, ${ }^{76}$ поэтому не случайно она не

psevdomorfozakh," L. O. Zaionts (red.), Zhivoi kamen': ot prirody k kul'ture (Moscow: Institut mirovoi kul'tury MGU, 2015), 213-4).

${ }^{70}$ М. Хагнер “Просвещенные монстры,” Д. Алкесандров, М. Хагнер (ред.), Наука и научность в исторической перспективе (Санкт-Петербург: Европейский университет в Санкт-Петербурге, Алетейя, 2007), 72-126 (М. Khagner, "Prosveshchennye monstry," D. Aleksandrov, M. Khagner (red.), Nauka i nauchnost' v istoricheskoi perspektive (St. Petersburg: Evropeiskii universitet v Sankt-Peterburge, Aleteiia, 2007), 72-126).

71 "Имеется также определенная напряженность между утверждениями Фонтенеля и Лейбница, с одной стороны, и Валентина - с другой; в то время как первые требовали итеграции монстров в правильный ход природных событий, последний исключал их из этой правильности, по крайней мере в эстетическом смысле." Там же, 75 (Tam zhe, 75).

${ }^{72}$ Там же, 72, 75 и далее (Tam zhe, 72, 75 i dalee).

${ }^{73}$ М. Фуко, Ненормальные: Курс лекций, прочитанный в Коллеж де Франс в 1974-1975 учебном году (Санкт-Петербург: Наука, 2005), 79-81 (М. Fuko, Nenormal'nye: Kurs lektsii, prochinannyi v Kollezh de Frans v 1974-1975 uchebnom godu (St. Petersburg: Nauka, 2005), 79-81).

${ }^{74}$ Ср.: "В лучших традициях мышления XVIII в. [...] мир полон диковин, которые для определения своей значимости нуждаются в сравнении друг с другом.” См.: А. Хеезен, "Коробки в природе и природы в коробках," Наука и научность в исторической перспективе, 141 (A. Kheezen, "Korobki v prirode i prirody v korobkakh," Nauka i nauchnost' v istoricheskoi perspektive, 141).

${ }_{75}$ C. von Linné, Caroli Linnaei, Sveci, Doctoris Medicinae systema naturae, sive, Regna tria naturae systematice proposita per classes, ordines, genera, E species (Leiden: Apud Theodorum Haak, 1735). Минералогическая систематика обозначена в этом сочинении как “Царство камня” (Regnum lapideum).

76 “При создании классификации минералов Линней попытался повторить то, что он сделал для растений и животных. Этот метод, который не учитывает химический состав и по своей природе предполагает органическое размножение, не подходит для неорганических продуктов природы, 
получила развития в минералогии ни современной, ни XVIII в. (что, опять же, не лишало ее права на существование).

Что же касается самого направления изменений и тенденций, которые можно разглядеть в действии различных научных систематик и подходов, то и здесь сложно согласиться с М. Хагнером. На всем протяжении XVIII в. происходило не “расколдовывание,"77 а “заколдовывание” вещей (к нашему времени приведшее к совершенной непонятности научного языка для “непосвященных," что, как было подробно показано, отчетливо видно по изменению описаний флорентийского мрамора в каталогах Минерального кабинета). В этом смысле к концу XVIII в. монстры (и, продолжая нашу аналогию, фигурные камни) вовсе не утратили свой статус как угроза порядку, ${ }^{78}$ а наоборот, приобрели его, и этот статус был за ними закреплен и уже не мог оспариваться, как в многочисленных Системах природы первой половины XVIII в. Специализация наук, рождение новых научных дисциплин в XVIII в. как раз маркировало собой процесс организации новых границ - между живым и неживым, между нормой и ненормальностью. ${ }^{79}$ Примерно к 8о-9о гг. XIX в. мы можем зафиксировать утверждение этих новых границ в минералогических коллекциях (исчезновение фигурных камней из “минеральных каталогов” Кунсткамеры), ${ }^{80}$ также к концу XVIII в. Мишель Фуко относит появление проблемы монстров. ${ }^{81}$ Возникновение “проблемы монстров” (как и проблемы “псевдоморфозы”) являлась следствием этого нового порядка вещей, а отнюдь не его причиной.

\section{Заключение}

Флорентийские мозаики из собрания Минерального кабинета Кунсткамеры, как показывают их описания в каталогах, в XVIII в. обладали значениями фигурных камней, своеобразных “монстров,” пограничных объектов, демонстрирующих одновременно и игры природы, и человеческое искусство, гибрид между произведением природы и произведением человеческого искусства. В этом своем качестве они были связаны с острыми научными проблемами и дискуссиями XVIII в.: обсуждением возможности и границ окаменения, взаимоотношений живой и неживой природы, нюансов минералообразования. Фигурные камни в XVIII в. маркируют в научном дискурсе проблематику различения подобий и

поэтому его минералогическая систематика не оказалась столь же полезной, как биологическая." Cм.: “LINNAEUS (Linné), Carl. (1707 - 1778)," Curtis Schuh's Bibliography of Mineralogy, The Library of the Mineralogical Record, http://www.minrec.org/libdetail.asp?id=876 (дата обращения 10.03.2017).

77 Хагнер, “Просвещенные монстры,” 73 и далее (Khagner, “Prosveshchennye monstry,” 73 i dalee).

${ }^{78}$ Там же, 119 (Tam zhe, 119).

79 А также новых отношений между познаваемым и непознаваемым: “Схема, которой открывается Энциклопедия Дидро (знаменитое древо знания, восходящее к Бэкону и Чэмберсу), представляла собой нечто новое и оригинальное. Вместо того, чтобы тасовать научные дисциплины в рамках установленной парадигмы, она замахивалась на отделение познаваемого от непознаваемого, исключая из мира учености большую часть того, что считалось священным.” Следя за изощренными попытками philosophes постричь доставшееся им от предшественников древо знания, можно яснее представить себе, ка много было поставлено на кон в просвещенческой версии энциклопедизма." См.: Р. Дарнтон, Великое кошачье побоище и другие эпизоды из истории французской культуры, пер. с англ. яз. Т. Доброницкой, С. Кулланыд (Москва: Новое литературное обозрение, 2002), 228) (R. Darnton, Velikoe koshach'e poboishche i drugie epizody iz istorii frantsuzskoi kul'tury, per. s angl. iaz. T. Dobronitskoi, S. Kullanyd (Moscow: Novoe literaturnoe obozrenie, 2002), 228).

${ }^{80}$ Enumeratio fossilium, л. 82-94.

${ }^{81}$ М. Фуко, Ненормальные, 81 (M. Fuko, Nenormal'nye, 81). 
псевдоморфоз, и на всем протяжении XVIII в. постепенно формулируется положение о том, что в природном “царстве минералов” нет вещей, подобных человеческому миру, а если же кажется, что они есть - это обман (или игра Природы или человеческого воображения, не требующая и не предусматривающая научного объяснения). ${ }^{82}$ Разница с современным значением флорентийских мозаик (и в целом камнерезных изделий) в минералогической коллекции очевидна: сейчас они репрезентируют в коллекции то, что называется “культурой камня" или “историей камня” (направление, которое начало развиваться в отечественных геолого-минералогических науках только в XX в., начиная с трудов академика Ферсмана). ${ }^{83}$

Однако коллекция ПДК современного минералогического музея репрезентирует минерал не только как материал, сырье, ресурс для художественного производства, но и как своего рода идеальное произведения искусства: уже не Природа, Минеральный мир подражает человеческому искусству (как это полагалось в трактовке фигурных камней в XVII - XVIII вв.), а ровно наоборот: “красота” становится имманентно присуща самоцвету, а критерием таланта художника становится его способность подражать Природе и ее творениям, искать в них подсказки и вдохновение для своего творчества (даже в самом слове "самоцветы," столь любимом Ферсманом, содержится эта идея: камень обладает красотой сам по себе, независимо от человеческого взгляда и суждения, а человеку остается только заметить эту красоту и использовать ее). Александр Евгеньевич Ферсман писал: “К цветному и драгоценному камню России и к его использованию можно подходить с нескольких точек зрения: чисто минералогической, промышленной, художественной, исторической. Я делаю попытку осветить этот многогранный вопрос со всех указанных выше точек зрения, но особенное внимание посвящаю тому, что лежит в основе всех остальных, - природе самого камня, его свойствам и происхождению. Выдвигая эти вопросы, я исхожу из мысли, что само промышленное, техническое или художественное использование камня является лишь выявлением тех характерных черт и элементов красоты, которыми его наделила природа и которые во всей своей совокупности и во всех своих деталях являются выражением и отражением геохимических процессов, сопутствовавших его образованию. Художественное творчество человека, интуитивно схватывающее в своих высоких достижениях характерные черты камни, связывается таким образом с глубокими научными проблемами его исследования, и при рассматривании обработки камня в исторической перспективе невольно вырисовывается эта связь, подчиняющая материалу и его свойствам творческих порыв народного искусства." 84

${ }^{82}$ Ср. поэтическое описание подобных камней у Р. Кайуа. См.: Р. Кайуа, В глубь фантастического. Отражённые камни, пер. с фр. Н. Кисловой (Санкт-Петербург: Изд-во Ивана Лимбаха, 2006), 129-152 (R. Kaiua, V glub' fantasticheskogo. Otrazhennye kamni, per. s fr. N. Kislovoi (St. Petersburg: Izd-vo Ivana Limbakha, 2006), 129-152).

${ }_{3}^{8}$ А. Е. Ферсман, Очерки по истории камня, т. I (Москва: Изд-во АН СССР, 1954) (А. E. Fersman, Ocherki po istorii kamnia, t. 1 (Moscow: Izd-vo AN SSSR, 1954)).

${ }^{84}$ А. Е. Ферсман, “Декоративные и цветные камни России," Монографии комиссии по изучению естественных производительных сил России Российской академии наук, т. 1. Описание драгоценных и цветных камней России (Петроград: 4-я Государственная Типография, 1920), 3 (A. E. Fersman, "Dekorativnye i tsvetnye kamni Rossii," Monografii komissii po izucheniiu estestvennykh proizvoditel'nykh sil Rossii Rossiiskoi akademii nauk, t. 1. Opisanie dragotsennykh i tsvetnykh kamnei Rossii (Petrograd: 4-ia Gosudarstvennaia Tipografiia, 1920), 3). Ср. также: “Я хотел бы, чтобы ваятель и зодчий увидели в камне нечто большее, чем простую глину, из которой скульптор лепит свой первый эскиз, нечто 
Добавим также, что уже в трудах В. И. Вернадского, ${ }^{85}$ в противоположность антропоморфности Природы, напротив - человек становится соприроден миру минералов: он становится геологическим агентом (подобно ветру, рекам, леднику и др.), участвует в геологических процессах, а сфера действия человеческого разума ноосфера - становится еще одной природной оболочкой Земли (наряду с астеносферой или атмосферой). ${ }^{86}$

В каталожных описаниях флорентийских мозаик из Минерального кабинета Кунсткамеры XVIII в. может быть ясно прослежена эта изящная игра значений: произведений играющей Природы, подражающей человеческому искусству, которым, в свою очередь подражают флорентийские мозаики. Именно это сложное переплетение значений и составляло смысл присутствия в Минеральном кабинете произведений искусства, флорентийских мозаик, и этот смысл отнюдь не являлся ненаучным в коллекции XVIII в.

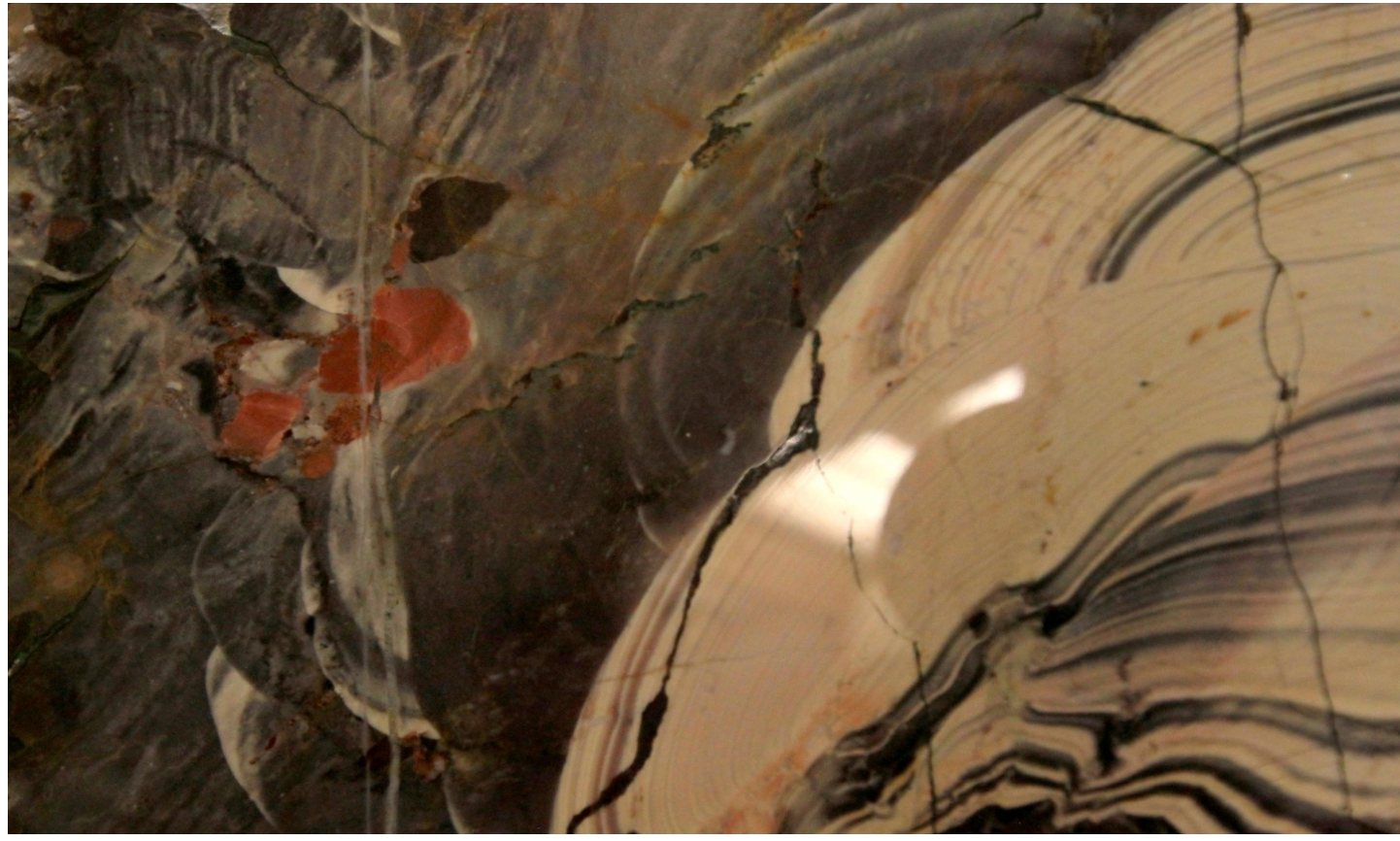

Фигура 7. Природное изображение “гейши” на полированной поверхности орской яшмы из экспозиции Минералогического музея им. А. Е. Ферсмана РАН. Фотография Д. Новгородовой.

Сейчас игры природы уже не изучаются минералогией, однако давно исчезнувшие из научной минералогической литературы, они парадоксальным

большее, чем простой кирпич, из которого архитектор и строитель воздвигают здания. Я хотел, чтобы в самом камне [курсив мой - Д.Н.], в его строении, форме, рисунке - во всех его свойствах, изучаемых наукой, они искали выражение своих творческих идей; чтобы они поняли, что на всем протяжении истории архитектуры и скульптуры камень в известной мере направлял пути этих видов искусства, определяя не только внешние его формы, но отчасти и внутреннее содержание.” См.: Ферсман, Очерки по истории камня, т. I, 9. (Fersman, Ocherki po istorii kamnia, t. I, 9).

${ }^{85}$ Академик В. И. Вернадский был директором Минералогического музея им. Ферсмана, 1906 - 1914 гг. (Минералогический отдел Геологического музея им. Петра Великого, с 1914 г. Минералогический музей РАН).

${ }^{86}$ См., например, первую главу (“отдел”) “Научная мысль и научная работа как геологическая сила в биосфере” в его незаконченной работе “Научная мысль как планетное явление,” опубликовано: В. И. Вернадский, "Научная мысль как планетное явление," Философские мысли натуралиста (Москва: Изд. Наука, 1988), 20-195 (V. I. Vernadskii, "Nauchnaia mysl' kak planetnoe iavlenie," Filosofskie mysli naturalista (Moscow: Izd. Nauka, 1988), 20-195). 
образом сохранили свое важное значение в музейной практике, более того, они активно действуют и развиваются. Нарратив “играющей Природы” - вполне в плинианском понимании - является одним из самых распространенных экспозиционных сюжетов минералогических выставок, которые можно объединить под условным (а иногда и буквальным) названием “Удивительное в камне.” Подобие - наделение мира минералов “чем-то человеческим" (в том числе через человеческое воображение, и обман зрения) до сих пор является содержательным элементом, формирующем значения коллекций минералогического музея и в целом минералогии “для простых зрителей.” Это подобие между произведениями Природы и человеческой культуры теперь уже не является научным признаком минерала, закрепленном в его формальном названии (как например "руинный мрамор”), но всегда - будто чудесной и только что открытой самой сутью того или иного раритетного образца. В Минералогическом музее им. Ферсмана экскурсии редко проходят мимо орской яшмы с полированным срезом, на котором “смотрите-ка! - если приглядеться, то можно разглядеть фигурку танцующей гейши.” (Фигура 7).

\section{Приложения}

Таблица 1. Мрамор. Флорентийская мозаика. Соответствие описания мраморных мозаик из Минерального каталога М. В. Ломоносова существующим образцам Минералогического музея им. А. Е. Ферсмана РАН. ${ }^{87}$

\begin{tabular}{|l|l|l|l|}
\hline Латинский текст & Русский текст & Фотографии & Инвентарные \\
Минерального & Минерального каталога & образцов мрамора & номера, \\
каталога 1745 г. & 1745 г. (Ломоносов, 1954, & Минералогического & указанные на \\
(Ломоносов, 1954, & 194). & музея им. А. Е. & обороте \\
26). & Ферсмана РАН. & образцов. \\
& Инвентарные & \\
& номера. & \\
& Размеры. & \\
\hline
\end{tabular}

\footnotetext{
${ }^{87}$ Впервые опубликовано: Новгородова, “Флорентийская мозаика," 141-3 (Novgorodova, "Florentiiskaia mozaika," 141-3).
} 


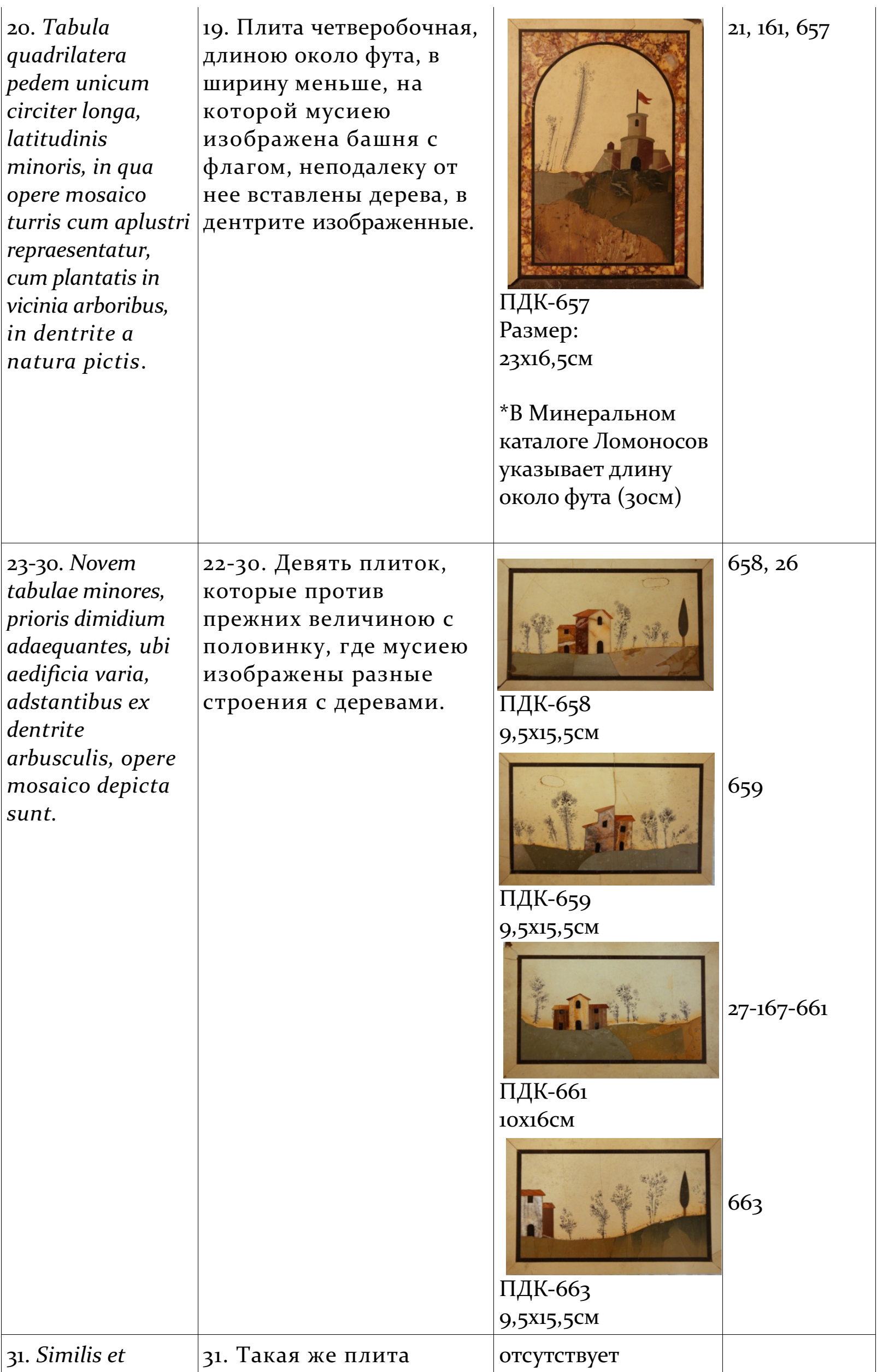




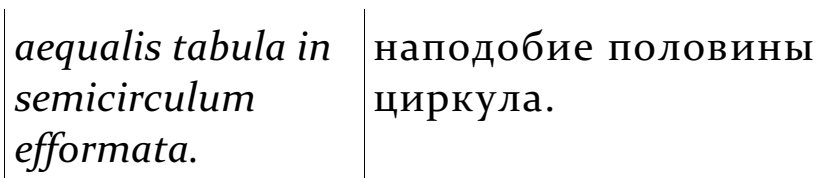

Таблица 2. Руинный (флорентийский) мрамор. Гипотетическое соответствие описания мраморных мозаик из Минерального каталога М. В. Ломоносова существующим образцам Минералогического музея им. А. Е. Ферсмана РАН. ${ }^{8}$

\begin{tabular}{|c|c|c|}
\hline $\begin{array}{l}\text { Латинский текст } \\
\text { Минерального } \\
\text { каталога } 1745 \text { г. } \\
\text { (Ломоносов, 1954, } \\
\text { 25). }\end{array}$ & $\begin{array}{l}\text { Русский текст } \\
\text { Минерального } \\
\text { каталога 1745 г. } \\
\text { (Ломоносов, 1954, 193- } \\
\text { 194). }\end{array}$ & $\begin{array}{l}\text { Фотографии } \\
\text { образцов } \\
\text { мрамора } \\
\text { Минералогич } \\
\text { еского музея } \\
\text { им. А. Е. } \\
\text { Ферсмана } \\
\text { РАН. } \\
\text { Инвентарные } \\
\text { номера. } \\
\text { Размеры. } \\
\text { * расчетный } \\
\text { размер } \\
\text { образцов, } \\
\text { указанный в } \\
\text { Минеральном } \\
\text { каталоге 1745 } \\
\text { г. }\end{array}$ \\
\hline $\begin{array}{l}\text { 1. Tabula } \\
\text { quadrilatera } \\
\text { oblonga, ex } \\
\text { Marmore Florentino } \\
\text { excisa, in quo rupes, } \\
\text { rudera et nubes ad } \\
\text { vivum depicta } \\
\text { conspiciuntur, } \\
\text { coloris fusci et } \\
\text { flaventis, ad } \\
\text { extremitates ejus } \\
\text { lamellae Marmoris } \\
\text { candidioris } \\
\text { agglutinatae sunt, } \\
\text { cancellorum instar. } \\
\text { Longitudo ejus } \\
\text { dimidium pedem } \\
\text { superat, latitudo vix } \\
\text { adaequat. }\end{array}$ & $\begin{array}{l}\text { 2о. Плитка } \\
\text { четвероугольная, } \\
\text { продолговатая, из } \\
\text { флоренского мрамора } \\
\text { высечена, на которой } \\
\text { каменные горы, } \\
\text { обрушившиеся здания и } \\
\text { облака в их натуральном } \\
\text { виде представлены, цвету } \\
\text { темножелтого. К краям сей } \\
\text { плитки приклеены } \\
\text { тоненькие дощечки белого } \\
\text { мармора наподобие рамок. } \\
\text { Она длиною больше } \\
\text { половины фута, а шириною } \\
\text { почти равна. }\end{array}$ & $\begin{array}{l}\text { ПДК-2095 } \\
13 \times 18 \mathrm{~cm} \\
{ }^{*} 15 \times 15 \mathrm{~cm}\end{array}$ \\
\hline
\end{tabular}

${ }^{88}$ Впервые опубликовано: idem, 144-6. 


\begin{tabular}{|c|c|c|}
\hline $\begin{array}{l}\text { 2. Similis tabula } \\
\text { minor per medium } \\
\text { vena Quarzi tendente } \\
\text { divisa. }\end{array}$ & $\begin{array}{l}\text { 2. Такая же плита, } \\
\text { прежней поменьше, } \\
\text { которую посредине } \\
\text { жила кварца } \\
\text { разделяет. }\end{array}$ & $\begin{array}{l}\text { D. } \\
\text { ПДК-2096 } \\
10 \times 21 \mathrm{cM}\end{array}$ \\
\hline $\begin{array}{l}\text { 3. Tabula hujusmodi } \\
\text { adhuc minor } \\
\text { fuscioris coloris. }\end{array}$ & $\begin{array}{l}\text { 3. Такая же плита, } \\
\text { прежней еще меньше } \\
\text { и цветом темнее. }\end{array}$ & $\begin{array}{l}\text { ПДК-662 } \\
10,5 \times 21 c \mathrm{M}\end{array}$ \\
\hline $\begin{array}{l}\text { 4. Tabula ex Marmore } \\
\text { Florentino, ut Nr. } 3 \text {, } \\
\text { confecta, } \\
\text { quadrangula, } 5 \\
\text { pollices circiter } \\
\text { longa, } 2 \text { lata, sine } \\
\text { marginibus, ex } \\
\text { Marmore candidiore. }\end{array}$ & $\begin{array}{l}\text { Плита из мрамора } \\
\text { флоренского, } \\
\text { темного цвету, видом } \\
\text { такая же, как под № } \\
3 \text {, четвероугольная, } \\
\text { длиною около } 5 \\
\text { дюймов, шириною в } \\
\text { два, без краев, } \\
\text { мрамору белого не } \\
\text { имеет. }\end{array}$ & $\begin{array}{l}\text { Отсутствует? } \\
\text { *5X12 cM }\end{array}$ \\
\hline $\begin{array}{l}\text { 5. Simile Marmor iri } \\
\text { tabulam ovalem } \\
\text { excisum. }\end{array}$ & $\begin{array}{l}\text { Такой же мрамор, } \\
\text { высечен наподобие } \\
\text { овальной плиты. }\end{array}$ & Отсутствует? \\
\hline $\begin{array}{l}\text { 6-9. Quatuor orbiculi } \\
\text { ex Marmore } \\
\text { Florentino flavente } \\
\text { fusciore diametri } \\
\text { bipollicaris. }\end{array}$ & $\begin{array}{l}\text { Четыре кружка из } \\
\text { мрамора флоренского } \\
\text { темножелтого, в } \\
\text { диаметре в два } \\
\text { дюйма. }\end{array}$ & 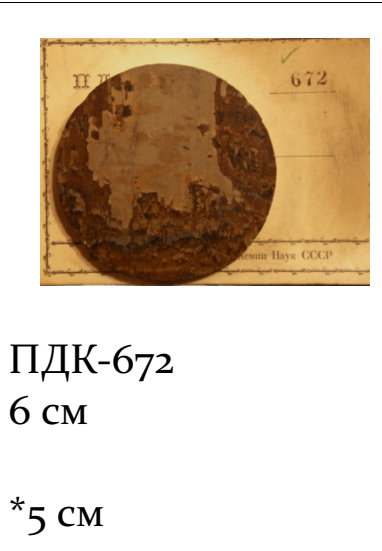 \\
\hline
\end{tabular}




\begin{tabular}{|c|c|c|}
\hline $\begin{array}{l}\text { 10-11. Duo orbes } \\
\text { majores ex Marmore } \\
\text { Florentino flavente } \\
\text { dilutiore. }\end{array}$ & $\begin{array}{l}\text { 10-11. Два кружка, } \\
\text { прежних побольше, из } \\
\text { мрамора флоренского } \\
\text { светложелтого. }\end{array}$ & $\begin{array}{l}\text { ПДК-4202 } \\
5 \times 5,7 \mathrm{CM}\end{array}$ \\
\hline $\begin{array}{l}\text { 12-18. Septem tabulae, } \\
\text { quatuor circiter } \\
\text { pollices longae, } 2 \text { latae } \\
\text { ex Marmore } \\
\text { Florentino fusciore, ut } \\
\text { est Nr. 6, excisae. }\end{array}$ & $\begin{array}{l}\text { 12-18. Семь плиток } \\
\text { длиною около } \\
\text { четырех дюймов, } \\
\text { шириною в два, из } \\
\text { мрамора } \\
\text { флоренского } \\
\text { темноватого, } \\
\text { подобно как под № } \\
6 .\end{array}$ & $\begin{array}{l}\text { ПДК-7835 } \\
8 \times 15 \mathrm{cM} \\
\text { ПДК-8099 } \\
10,5 \times 17 \mathrm{CM} \\
\text { * } 5 \text { Х10 см }\end{array}$ \\
\hline
\end{tabular}

